\title{
Carbon Dioxide: Capturing and Utilization
}

\author{
Ali Kargari ${ }^{1}$ and Maryam Takht Ravanchi ${ }^{2}$ \\ ${ }^{1}$ Amirkabir University of Technology (Tehran Polytechnic) \\ ${ }^{2}$ National Petrochemical Company, Petrochemical Research and Technology Co \\ Islamic Republic of Iran
}

\section{Introduction}

The global warming issue is one of the most important environmental issues that impacts on the very foundations of human survival.

One person emits about 20 tons of $\mathrm{CO}_{2}$ per year. Combustion of most carbon-containing substances produces $\mathrm{CO}_{2}$. Energy utilization in modern societies today is based on combustion of carbonaceous fuels, which are dominated by the three fossil fuels: coal, petroleum, and natural gas. Complete oxidation or combustion of any carbon-based organic matter produces $\mathrm{CO}_{2}$.

Carbon dioxide makes up just 0.035 percent of the atmosphere, but is the most abundant of the greenhouse gases (GHG) which include methane, nitrous oxide, ozone, and CFCs. All of the greenhouse gases play a role in protecting the earth from rapid loss of heat during the nighttime hours, but abnormally high concentrations of these gases are thought to cause overall warming of the global climate. Governments around the world are now pursuing strategies to halt the rise in concentrations of carbon dioxide and other greenhouse gases (Climate Change 2007). Presently it is estimated that more than 30 billion metric tons of $\mathrm{CO}_{2}$ is generated annually by the human activities in the whole world. It is reported that approximately 80 percent of the total which is about 24 billion tons is unfortunately originated from only 20 countries. Table 1 shows a list of the most contributed countries in $\mathrm{CO}_{2}$ emissions. In addition to the efforts for reduction of $\mathrm{CO}_{2}$, a new technology to collect and store $\mathrm{CO}_{2}$ is being aggressively developed. The technology is so called CCS which means Carbon dioxide Capture \& Storage. Many scientists have concluded that the observed global climate change is due to the greenhouse gas effect, in which man-made greenhouse gases alter the amount of thermal energy stored in the Earth's atmosphere, thereby increasing atmospheric temperatures. The greenhouse gas produced in the most significant quantities is carbon dioxide. The primary source of man-made $\mathrm{CO}_{2}$ is combustion of fossil fuels. Stabilizing the concentration of atmospheric $\mathrm{CO}_{2}$ will likely require a variety of actions including a reduction in $\mathrm{CO}_{2}$ emissions. Since the Industrial Age, the concentration of carbon dioxide in the atmosphere has risen from about $280 \mathrm{ppm}$ to $377 \mathrm{ppm}$, a 35 percent increase. The concentration of carbon dioxide in Earth's atmosphere is approximately $391 \mathrm{ppm}$ by volume as of 2011 and rose by $2.0 \mathrm{ppm} / \mathrm{yr}$ during 2000-2009. Forty years earlier, the rise was only $0.9 \mathrm{ppm} / \mathrm{yr}$, showing not only increasing concentrations, but also a rapid acceleration of concentrations. The increase of concentration from pre-industrial concentrations has again doubled in just the last 31 years. 


\begin{tabular}{|c|c|c|c|}
\hline Rank & Country & $\begin{array}{c}\text { Annual } \mathrm{CO}_{2} \text { emissions } \\
\text { (in } 1000 \mathrm{Mt} \text { ) }\end{array}$ & $\%$ of global total \\
\hline 1 & China & $7,031,916$ & $23.33 \%$ \\
\hline 2 & United States & $5,461,014$ & $18.11 \%$ \\
\hline 3 & India & $1,742,698$ & $5.78 \%$ \\
\hline 4 & Russia & $1,708,653$ & $5.67 \%$ \\
\hline 5 & Japan & $1,208,163$ & $4.01 \%$ \\
\hline 6 & Germany & 786,660 & $2.61 \%$ \\
\hline 7 & Canada & 544,091 & $1.80 \%$ \\
\hline 8 & Iran & 538,404 & $1.79 \%$ \\
\hline 9 & United Kingdom & 522,856 & $1.73 \%$ \\
\hline 10 & South Korea & 509,170 & $1.69 \%$ \\
\hline 11 & Mexico & 475,834 & $1.58 \%$ \\
\hline 12 & Italy & 445,119 & $1.48 \%$ \\
\hline 13 & South Africa & 435,878 & $1.45 \%$ \\
\hline 14 & Saudi Arabia & 433,557 & $1.44 \%$ \\
\hline 15 & Indonesia & 406,029 & $1.35 \%$ \\
\hline 16 & Australia & 399,219 & $1.32 \%$ \\
\hline 17 & Brazil & 393,220 & $1.30 \%$ \\
\hline 18 & France & 376,986 & $1.25 \%$ \\
\hline 19 & Spain & 329,286 & $1.09 \%$ \\
\hline 20 & Ukraine & 323,532 & $1.07 \%$ \\
\hline 21 & Poland & 316,066 & $1.05 \%$ \\
\hline 22 & Thailand & 285,733 & $0.95 \%$ \\
\hline 23 & Turkey & 283,980 & $0.94 \%$ \\
\hline 24 & Taiwan & 258,599 & $0.86 \%$ \\
\hline 25 & Kazakhstan & 236,954 & $0.79 \%$ \\
\hline 26 & Egypt & 210,321 & $0.70 \%$ \\
\hline 27 & Malaysia & 208,267 & $0.69 \%$ \\
\hline 28 & Argentina & 192,378 & $0.64 \%$ \\
\hline 29 & Netherlands & 173,750 & $0.58 \%$ \\
\hline 30 & Venezuela & 169,533 & $0.56 \%$ \\
\hline 31 & Pakistan & 163,178 & $0.54 \%$ \\
\hline 32 & United Arab Emirates & 155,066 & $0.51 \%$ \\
\hline 33 & Other countries & $3,162,011$ & $11.34 \%$ \\
\hline & World & $29,888,121$ & $100 \%$ \\
\hline
\end{tabular}

Table 1. List of countries by 2008 emissions (IEAW, 2010)

Carbon dioxide is essential to photosynthesis in plants and other photoautotrophs, and is also a prominent greenhouse gas. Despite its relatively small overall concentration in the atmosphere, $\mathrm{CO}_{2}$ is an important component of Earth's atmosphere because it absorbs and emits infrared radiation at wavelengths of $4.26 \mu \mathrm{m}$ (asymmetric stretching vibrational mode) and $14.99 \mu \mathrm{m}$ (bending vibrational mode), thereby playing a role in the greenhouse effect, although water vapour plays a more important role. The present level is higher than at any time during the last 800 thousand years and likely higher than in the past 20 million years.

To avoid dangerous climate change, the growth of atmospheric concentrations of greenhouse gases must be halted, and the concentration may have to be reduced (Mahmoudkhani \& Keith, 2009). 
There are three options to reduce total $\mathrm{CO}_{2}$ emission into the atmosphere:

- $\quad$ Reduce energy intensity

- Reduce carbon intensity, and

- $\quad$ Enhance the sequestration of $\mathrm{CO}_{2}$.

The first option requires efficient use of energy. The second option requires switching to using non-fossil fuels such as hydrogen and renewable energy. The third option involves the development of technologies to capture, sequester and utilize more $\mathrm{CO}_{2}$.

\section{Sources of $\mathrm{CO}_{2}$}

About $85 \%$ of the world's commercial energy needs are currently supplied by fossil fuels. A rapid change to non-fossil energy sources would result in large disruption to the energy supply infrastructure, with substantial consequences for the global economy. The technology of $\mathrm{CO}_{2}$ capture and storage would enable the world to continue to use fossil fuels but with much reduced emissions of $\mathrm{CO}_{2}$, while other low- $\mathrm{CO}_{2}$ energy sources are being developed and introduced on a large scale. In view of the many uncertainties about the course of climate change, further development and demonstration of $\mathrm{CO}_{2}$ capture and storage technologies is a prudent precautionary action. Global emissions of $\mathrm{CO}_{2}$ from fossil fuel use were 23684 million tons per year in 2001. These emissions are concentrated in four main sectors: power generation, industrial processes, the transportation sector and residential and commercial buildings, as shown in Figure 1(a) (IEA, 2003) also, Figure 1 (b and c) depicts the distribution of the flue gases produced by these fuels showing that the major part of the effluent gases is $\mathrm{N}_{2}, \mathrm{H}_{2} \mathrm{O}, \mathrm{CO}_{2}$, and $\mathrm{O}_{2}$, respectively (Moghadassi et al., 2009).

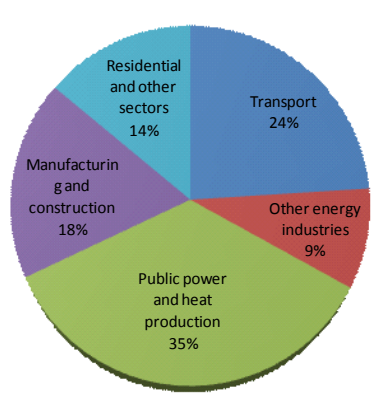

(a)

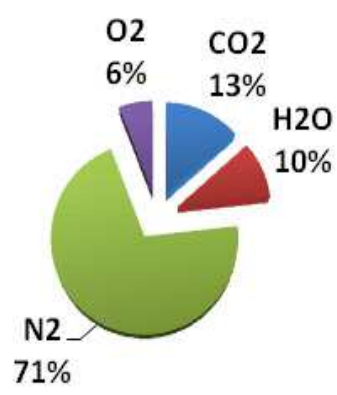

(b)

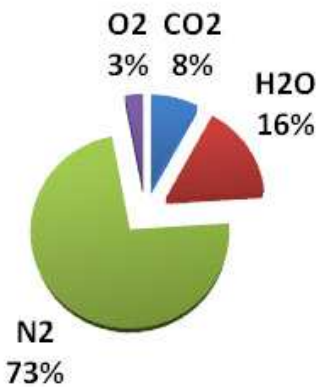

(c)

Fig. 1. (a) The emissions contribution of $\mathrm{CO}_{2}$ from fossil fuels use in 2001, total emissions $23684 \mathrm{Mt} / \mathrm{y}$ and typical power station flue gas compositions, by the use of (a) coal and (b) natural gas as a fuel.

Table 2 shows the worldwide large stationary $\mathrm{CO}_{2}$ sources emitting more than $0.1 \mathrm{Mt} \mathrm{CO}_{2}$ per year. Most of the emissions of $\mathrm{CO}_{2}$ to the atmosphere from the electricity generation and industrial sectors are currently in the form of flue gas from combustion, in which the $\mathrm{CO}_{2}$ concentration is typically $4-14 \%$ by volume, although $\mathrm{CO}_{2}$ is produced at high concentrations by a few industrial processes. In principle, flue gas could be stored, to avoid 
emissions of $\mathrm{CO}_{2}$ to the atmosphere it would have to be compressed to a pressure of typically more than $10 \mathrm{MPa}$ and this would consume an excessive amount of energy. Also, the high volume of flue gas would mean that storage reservoirs would be filled quickly. For these reasons it is preferable to produce a relatively high purity stream of $\mathrm{CO}_{2}$ for transport and storage; this process is called $\mathrm{CO}_{2}$ capture (Lotz \& Brent, 2008).

\begin{tabular}{|l|c|c|}
\hline \multicolumn{1}{|c|}{ Process } & $\begin{array}{c}\text { Number of } \\
\text { sources }\end{array}$ & $\begin{array}{c}\text { Emissions } \\
\left(\mathbf{M t ~} \mathrm{CO}_{2} \text { per year }\right)\end{array}$ \\
\hline Fossil fuels & 4942 & 10539 \\
Power & 1175 & 932 \\
Cement production & 638 & 798 \\
Refineries & 269 & 646 \\
Iron and steel industry & 470 & 379 \\
Petrochemical industry & Not available & 50 \\
Oil and gas processing & 90 & 33 \\
Other sources & & 303 \\
\hline Biomass & 91 & 7887 \\
Bioethanol and bioenergy & $\mathbf{1 3 4 6 6}$ & \\
\hline \multicolumn{2}{|c|}{ Total } &
\end{tabular}

Table 2. Worldwide large stationary $\mathrm{CO}_{2}$ sources emitting more than $0.1 \mathrm{Mt} \mathrm{CO}_{2}$ per year (Lotz \& Brent, 2008).

\section{$2.1 \mathrm{CO}_{2}$ large point sources}

Power generation is the largest source of $\mathrm{CO}_{2}$ which could be captured and stored. However, substantial quantities of $\mathrm{CO}_{2}$ could also be captured in some large energy consuming industries, in particular iron and steel, cement and chemicals production and oil refining.

\subsubsection{Cement production}

The largest industrial source of $\mathrm{CO}_{2}$ is cement production, which accounts for about $5 \%$ of global $\mathrm{CO}_{2}$ emissions. The quantity of $\mathrm{CO}_{2}$ produced by a new large cement kiln can be similar to that produced by a power plant boiler. About half of the $\mathrm{CO}_{2}$ from cement production is from fuel use and the other half is from calcination of $\mathrm{CaCO}_{3}$ to $\mathrm{CaO}$ and $\mathrm{CO}_{2}$. The concentration of $\mathrm{CO}_{2}$ in the flue gas from cement kilns is between 14 and $33 \mathrm{vol} \%$, depending on the production process and type of cement. This is higher than in power plant flue gas, so cement kilns could be good candidates for post-combustion $\mathrm{CO}_{2}$ capture. It may be advantageous to use oxyfuel combustion in cement kilns because only about half as much oxygen would have to be provided per tone of $\mathrm{CO}_{2}$ captured. However, the effects on the process chemistry of the higher $\mathrm{CO}_{2}$ concentration in the flue gas would have to be assessed (Henriks et. al., 1999).

\subsubsection{Iron and steel production}

Large integrated steel mills are some of the world's largest point sources of $\mathrm{CO}_{2}$. About $70 \%$ of the $\mathrm{CO}_{2}$ from integrated steel mills could be recovered by capture of the $\mathrm{CO}_{2}$ contained in blast furnace gas. Blast furnace gas typically contains $20 \%$ by volume $\mathrm{CO}_{2}$ and $21 \% \mathrm{CO}$, with the rest being mainly $\mathrm{N}_{2}$. An important and growing trend is the use of new processes for 
direct reduction of iron ore. Such processes are well suited to $\mathrm{CO}_{2}$ capture (Freund \& Gale, 2001).

\subsubsection{Oil refining}

About $65 \%$ of the $\mathrm{CO}_{2}$ emissions from oil refineries are from fired heaters and boilers (Freund \& Gale, 2001). The flue gases from these heaters and boilers are similar to those from power plants, so $\mathrm{CO}_{2}$ could be captured using the same techniques and at broadly similar costs. The same would be true for major fired heaters in the petrochemical industry, such as ethylene cracking furnaces.

\subsubsection{Hydrogen and ammonia production}

Large quantities of hydrogen are produced by reforming of natural gas, mainly for production of ammonia-based fertilizers. $\mathrm{CO}_{2}$ separated in hydrogen plant is normally vented to the atmosphere but it could instead be compressed for storage. This would be a relatively low cost method of avoiding release of $\mathrm{CO}_{2}$ to the atmosphere. It could also provide useful opportunities for the early demonstration of $\mathrm{CO}_{2}$ transport and storage techniques.

\subsubsection{Natural gas purification}

Some natural gas fields contain substantial amounts of $\mathrm{CO}_{2}$. The $\mathrm{CO}_{2}$ concentration has to be reduced to $\sim 2.5 \%$ for the market, so any excess $\mathrm{CO}_{2}$ has to be separated. The captured $\mathrm{CO}_{2}$ is usually vented to the atmosphere but, instead, it could be stored in underground reservoirs. The first example of this being done on a commercial scale is the Sleipner Vest gas field in the Norwegian sector of the North Sea (Torp \& Gale, 2002).

\subsubsection{Energy carriers for distributed energy users}

A large amount of fossil fuel is used in transport and small-scale heat and power production. It is not practicable using current technologies to capture, collect, and store $\mathrm{CO}_{2}$ from such small scale dispersed users. Nevertheless, large reductions could be made in $\mathrm{CO}_{2}$ emissions through use of a carbon-free energy carrier, such as hydrogen or electricity. Both hydrogen and electricity are often considered as a carrier for energy from renewable sources. However, they can also be produced from fossil fuels in large centralized plants, using capture and storage technology to minimize release of $\mathrm{CO}_{2}$. Production of hydrogen or electricity from fossil fuels with $\mathrm{CO}_{2}$ storage could be an attractive transitional strategy to aid the introduction of future carbon free energy carriers (Audus et. al., 1996).

\section{Kyoto protocol}

The global warming issue forces us to make efforts to use resources and energy efficiently and to reconsider socioeconomic activities and lifestyles that involve large volumes of production, consumption and waste. In June 1992, the Rio de Janeiro United Nations Conference on Environment and Development agreed on the United Nations Framework Convention on Climate Change (UNFCCC), an international treaty aiming at stabilizing greenhouse gas concentrations in the atmosphere. Greenhouse gases such as carbon dioxide $\left(\mathrm{CO}_{2}\right)$ or methane are considered responsible for global warming and climate change. Table 3 


\begin{tabular}{|c|c|c|c|}
\hline Gas & $\begin{array}{c}\text { Global } \\
\text { warming } \\
\text { Potential* }\end{array}$ & $\begin{array}{l}\text { Contribution } \\
\text { to global } \\
\text { warming }\end{array}$ & Major sources \\
\hline $\begin{array}{l}\text { Energy-originated } \\
\mathrm{CO}_{2}\end{array}$ & \multirow[t]{2}{*}{1} & \multirow[t]{2}{*}{$76 \%$} & $\begin{array}{l}\text { From fossil fuels both from direct consumption of } \\
\text { heating oil, gas, etc. and indirect from fossil fuels } \\
\text { for electricity production. }\end{array}$ \\
\hline $\begin{array}{l}\text { Non-energy- } \\
\text { originated } \mathrm{CO}_{2}\end{array}$ & & & $\begin{array}{l}\text { From use of limestone, incineration of waste, etc. } \\
\text { in industrial processes. }\end{array}$ \\
\hline $\mathrm{CH}_{4}$-(Methane) & 21 & $12 \%$ & $\begin{array}{l}\text { From anaerobic fermentation, etc. of organic } \\
\text { matter in paddy fields and waste disposal sites. }\end{array}$ \\
\hline $\begin{array}{l}\mathrm{N}_{2} \mathrm{O} \text { - (Nitrous } \\
\text { oxide) }\end{array}$ & 310 & $11 \%$ & $\begin{array}{l}\text { Generated in some manufacturing processes for } \\
\text { raw materials for chemical products, the } \\
\text { decomposition process of microorganisms in } \\
\text { livestock manure, etc. }\end{array}$ \\
\hline $\begin{array}{l}\text { HFC- } \\
\text { (Hydrofluoro- } \\
\text { carbons) }\end{array}$ & $140-11700$ & $<1 \%$ & $\begin{array}{l}\text { Used in the refrigerant in refrigeration and air } \\
\text { conditioning appliances, and in foaming agents } \\
\text { such as heat insulation materials, etc. }\end{array}$ \\
\hline $\begin{array}{l}\text { PFC- (Perfluoro } \\
\text { Carbons) }\end{array}$ & 7400 & $<1 \%$ & $\begin{array}{l}\text { Used in manufacturing processes for } \\
\text { semiconductors, etc. }\end{array}$ \\
\hline $\begin{array}{l}\mathrm{SF}_{6}-(\text { Sulfur } \\
\text { hexafluoride) }\end{array}$ & 25000 & $<1 \%$ & $\begin{array}{l}\text { In cover gas when making a magnesium solution, } \\
\text { manufacturing of semiconductors and electrical } \\
\text { insulation gas, etc. }\end{array}$ \\
\hline
\end{tabular}

Table 3. The global warming potential and major sources subject to the Kyoto protocol.

is a list of most important gases and their global warming potential according to the Kyoto protocol. In 1997, world leaders negotiated the so-called Kyoto protocol as an amendment to the UNFCCC. Under the protocol, industrialized countries committed themselves to a concrete and binding reduction of their collective greenhouse gas emissions $(5.2 \%$ by 2012 compared to 1990 levels). Currently and within the framework of the UNFCCC, international negotiations try to establish new reduction goals for the post-2012 second commitment period. The December 2009 Copenhagen conference is expected to fix a concrete agreement (UNFCCC, 1992).

The Kyoto Protocol puts a cap on the emissions of these 6 greenhouse gases by industrialized countries (also called Annex I Parties) to reduce their combined emissions by at least 5\% of their 1990 levels by the period 2008-2012. In order to minimize the cost of reducing emissions, the Kyoto Protocol has provided for 3 mechanisms that will allow industrialized countries flexibility in meeting their commitments:

- International emissions trading (ET) - trading of emission permits (called Assigned Amount Units or AAUs) among the industrialized countries.

- Joint Implementation (JI) - crediting of emission offsets resulting from projects among industrialized countries (called Emission Reduction Units or ERUs).

- Clean Development Mechanism (CDM) - crediting of emission offsets resulting from projects in developing countries (called Certified Emission Reductions or CERs). 


\section{Carbon Capture and Storage (CCS)}

Carbon capture and storage (CCS) technologies offer great potential for reducing $\mathrm{CO}_{2}$ emissions and mitigating global climate change, while minimizing the economic impacts of the solution. It seems that along with development of clean technologies, which are a long time program, the need for an emergency solution is vital. Capturing and storage of carbon dioxide is an important way to reduce the negative effects of the emissions. There are several technologies for CCS, some currently are used in large capacities and some are in the research phases. These technologies can be classified, based on their maturity for industrial application, into four classes (IPCC, 2006):

1. "Mature market" such as industrial separation, pipeline transport, enhanced oil recovery and industrial utilization.

2. "Economically feasible" such as post-combustion capture, pre-combustion capture, tanker transport, gas and oil fields and saline aquifers.

3. "Demonstration phase" such as oxy-fuel combustion and enhanced coal bed methane.

4. "Research phase" such as ocean storage and mineral carbonation.

Table 4 shows the predicted amounts of $\mathrm{CO}_{2}$ emission and capture from 2010 to 2050.

Table 5 shows the planned $\mathrm{CO}_{2}$ capture and storage projects including the location, size, capture process, and start-up date. Figure 2 demonstrates an overview of $\mathrm{CO}_{2}$ capture processes and systems (IPCC, 2006). There are three known method for capturing of $\mathrm{CO}_{2}$ in fossil fuels combustion systems. They are applicable in the processes where the main purpose is heat and power generation such as power generation stations. Following is a brief description of there three important capturing processes (WRI, 2008).

\begin{tabular}{|c|l|c|c|c|c|c|}
\hline \multirow{2}{*}{ Type of data } & \multicolumn{1}{|c|}{ Sector } & $\mathbf{2 0 1 0}$ & $\mathbf{2 0 2 0}$ & $\mathbf{2 0 3 0}$ & $\mathbf{2 0 4 0}$ & $\mathbf{2 0 5 0}$ \\
\hline \multirow{5}{*}{$\mathrm{CO}_{2}$ emission } & Power production & $\mathbf{1 2 0 1 4}$ & 13045 & 10999 & 7786 & 4573 \\
\cline { 2 - 7 } & Industry & 5399 & 5715 & 5277 & 4385 & 3493 \\
\cline { 2 - 7 } & Transportation & 7080 & 8211 & 8237 & 6733 & 5228 \\
\cline { 2 - 7 } & Other sources & 4589 & 4894 & 5072 & 5072 & 5072 \\
\cline { 2 - 7 } & Total & $\mathbf{2 9 0 8 3}$ & $\mathbf{3 1 8 6 4}$ & $\mathbf{2 9 5 8 6}$ & $\mathbf{2 3 9 7 6}$ & $\mathbf{1 8 3 6 7}$ \\
\hline \multirow{5}{*}{$\mathrm{CO}_{2}$ capture } & Power production & 0 & 340 & 2750 & 5963 & 9176 \\
\cline { 2 - 7 } & Industry & 0 & 66 & 699 & 1591 & 2483 \\
\cline { 2 - 7 } & Transportation & 0 & 148 & 1046 & 2550 & 4055 \\
\cline { 2 - 7 } & Other sources & 0 & 0 & 0 & 0 & 0 \\
\cline { 2 - 7 } & Total & $\mathbf{0}$ & $\mathbf{5 5 4}$ & $\mathbf{4 4 9 4}$ & $\mathbf{1 0 1 0 4}$ & $\mathbf{1 5 7 1 3}$ \\
\hline \multicolumn{2}{|c|}{ Accumulated $\mathrm{CO}_{2}$ capture (all sectors) } & 0 & 1672 & 28468 & 104262 & 236151 \\
\hline
\end{tabular}

Table 4. Predicted $\mathrm{CO}_{2}$ emission and capture globally in million tones. (Stangeland, 2007). 


\begin{tabular}{|c|c|c|c|c|c|}
\hline Project Name & Location & Feedstock & $\begin{array}{c}\text { Size (MW, } \\
\text { except as noted) }\end{array}$ & $\begin{array}{l}\text { Capture } \\
\text { Process }\end{array}$ & $\begin{array}{l}\text { Start-up } \\
\text { Date }\end{array}$ \\
\hline Total Lacq & France & Oil & 35 & Oxf & 2008 \\
\hline Vattenfall Oxyfuel & Germany & Coal & $30 / 300 / 1000^{*}$ & Oxf & $2008-15$ \\
\hline $\begin{array}{l}\text { AEP Alstom } \\
\text { Mountaineer }\end{array}$ & USA & Coal & 30 & Poc & 2008 \\
\hline Callide-A Oxy Fuel & Australia & Coal & 30 & Oxf & 2009 \\
\hline GreenGen & China & Coal & $250 / 800^{* *}$ & Prc & 2009 \\
\hline Williston & USA & Coal & 450 & Poc & $2009-15$ \\
\hline Kimberlina & USA & Coal & 50 & Oxf & 2010 \\
\hline NZEC & China & Coal & Undecided & Undecided & 2010 \\
\hline $\begin{array}{l}\text { AEP Alstom } \\
\text { Northeastern }\end{array}$ & USA & Coal & 200 & Poc & 2011 \\
\hline Sargas Husnes & Norway & Coal & 400 & Poc & 2011 \\
\hline $\begin{array}{l}\text { Scottish \& Southern } \\
\text { Energy Ferrybridge }\end{array}$ & UK & Coal & 500 & Poc & 2011-12 \\
\hline Naturkraft Kårstø & Norway & Gas & 420 & Poc & 2011-12 \\
\hline Fort Nelson & Canada & Gas & Gas Process & Prc & 2011 \\
\hline ZeroGen & Australia & Coal & 100 & Prc & 2012 \\
\hline WA Parish & USA & Coal & 125 & Poc & 2012 \\
\hline UAE Project & UAE & Gas & 420 & Prc & 2012 \\
\hline Appalachian Power & USA & Coal & 629 & Prc & 2012 \\
\hline $\begin{array}{l}\text { Wallula Energy } \\
\text { Resource Center }\end{array}$ & USA & Coal & $600-700$ & Prc & 2013 \\
\hline RWE power Tilbury & UK & Coal & 1600 & Poc & 2013 \\
\hline Tenaska & USA & Coal & 600 & Poc & 2014 \\
\hline UK CCS Project & UK & Coal & $300-400$ & Poc & 2014 \\
\hline Statoil Mongstad & Norway & Gas & $630 \mathrm{CHP}$ & Poc & 2014 \\
\hline RWE Zero CO2 & Germany & Coal & 450 & Prc & 2015 \\
\hline Monash Energy & Australia & Coal & $60,000 \mathrm{bpd}$ & Prc & 2016 \\
\hline Powerfuel Hatfield & UK & Coal & 900 & Prc & Undecided \\
\hline $\begin{array}{l}\text { ZENG Worsham- } \\
\text { Steed }\end{array}$ & USA & Gas & 70 & Oxf & Undecided \\
\hline Polygen Project & Canada & Coal/ Pcoke & 300 & Prc & Undecided \\
\hline ZENG Risavika & Norway & Gas & $50-70$ & Oxf & Undecided \\
\hline E.ON Karlshamn & Sweden & Oil & 5 & Poc & Undecided \\
\hline
\end{tabular}

* 30/300/1000 = Pilot (start time 2008)/Demo/Commercial (anticipated start time 2010-2015)

** 250/800 $=$ Demo $/$ Commercial

bpd = barrels per day; $\mathrm{CHP}=$ combined heat and power; $\mathrm{Pcoke}=$ petroleum coke; $\mathrm{Prc}=$ Pre-combustion;

$\mathrm{Poc}=$ Post-combustion; $\mathrm{Oxf}=\mathrm{Oxi}-\mathrm{fuel}$

Table 5. Planned $\mathrm{CO}_{2}$ capture and storage projects (MIT, 2008). 


\subsection{Post-combustion capture}

In order to separate the $\mathrm{CO}_{2}$ from the other flue gas components and concentrate the $\mathrm{CO}_{2}$, it is necessary to add a capture and a compression system (for storage and transport) to the post-combustion system. Advanced post-combustion capture technologies also require significant cleaning of the flue gas before the capture device particularly, sulfur levels have to be low (less than $10 \mathrm{ppm}$ and possibly lower) to reduce corrosion and fouling of the system.

Figure 3 shows a simple block diagram for post-combustion capture from a power plant.

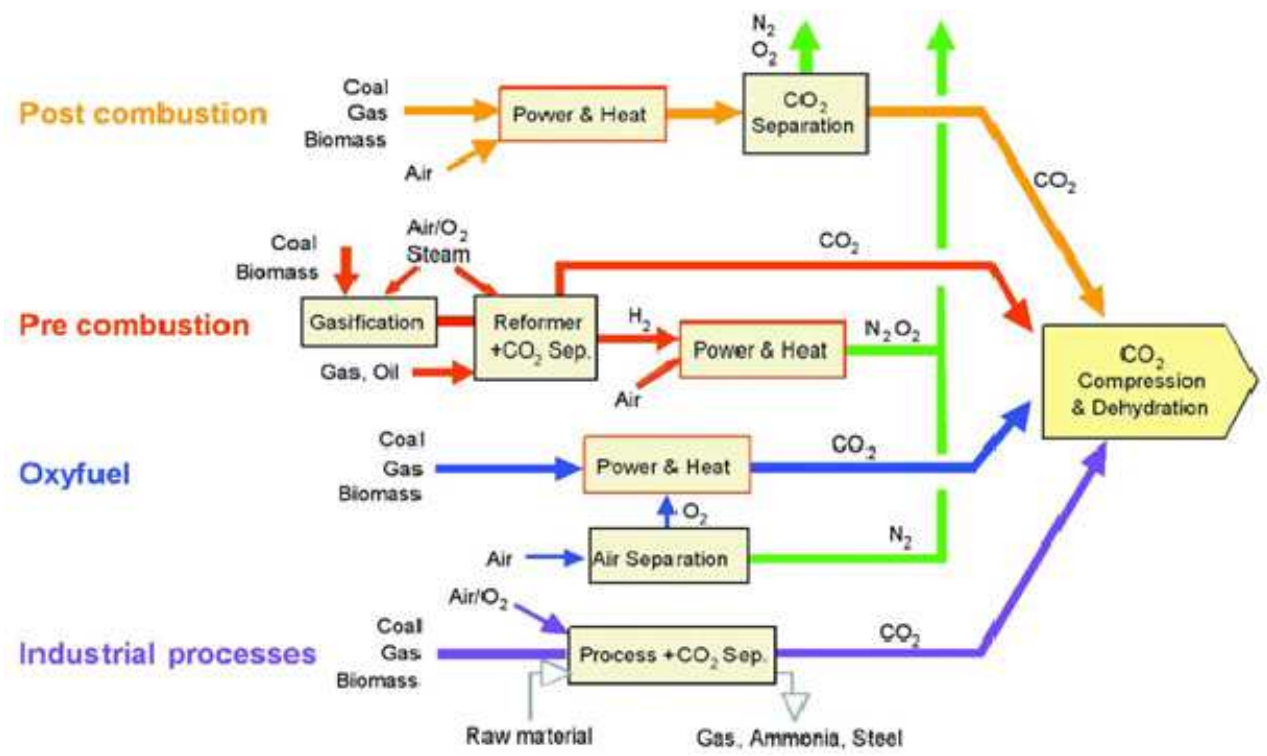

Fig. 2. Overview of $\mathrm{CO}_{2}$ capture processes and systems.

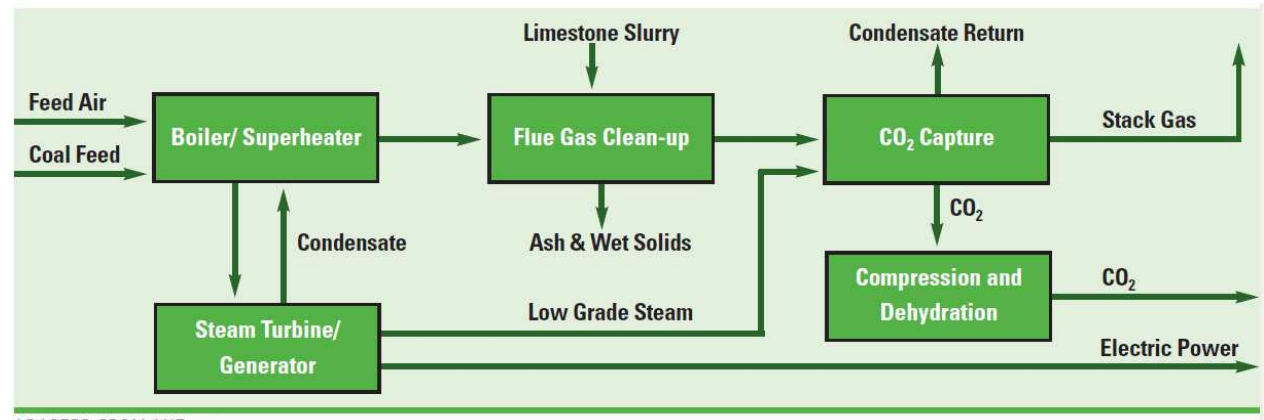

ADAPTED FROM MIT 2007

Fig. 3. Post-Combustion Capture from a Pulverized Coal-Fired Power Plant. 


\subsection{Pre-combustion capture}

Pre-combustion capture involves the removal of $\mathrm{CO}_{2}$ after the coal is gasified into syngas, but before combustion in an Integrated coal Gasification Combined Cycle (IGCC) unit (Figure 4). The first step involves gasifying the coal. Then, a water-gas shift reactor is used to convert carbon monoxide in the syngas and steam to $\mathrm{CO}_{2}$ and hydrogen. The $\mathrm{CO}_{2}$ is removed using either a chemical or a physical solvent, such as Selexol ${ }^{\mathrm{TM}}$, and is compressed. The hydrogen is combusted in a turbine to generate electricity. Because of technical problems, only $4 \mathrm{GW}$ of IGCC power plants have been built worldwide until the end of 2007.

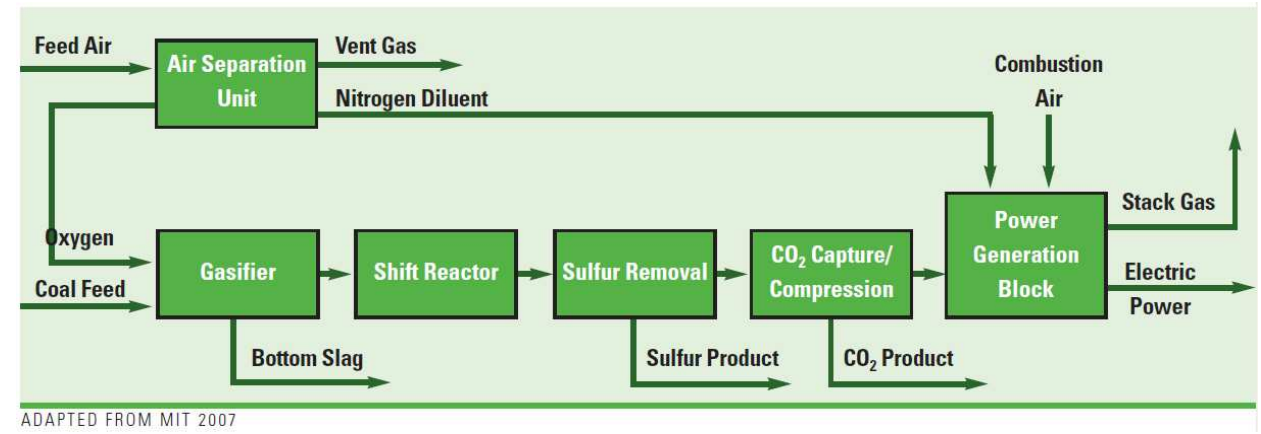

Fig. 4. Pre-Combustion Capture on an IGCC Power Plant.

\subsection{Oxy-fuel combustion}

Oxy-fuel combustion involves the combustion of fossil fuels in an oxygen-rich environment (nearly pure oxygen mixed with recycled exhaust gas), instead of air. This reduces the formation of nitrogen oxides, so that the exhaust gas is primarily $\mathrm{CO}_{2}$ and is easier to separate and remove (Figure 5). An air separation unit supplies oxygen to the boiler where it mixes with the recycled exhaust gas. After combustion, the gas stream can be cleaned of PM, nitrogen oxides, and sulfur. After condensing out the water, the flue gas has a $\mathrm{CO}_{2}$ concentration that is high enough to allow direct compression. As of 2008, oxy-fuel power

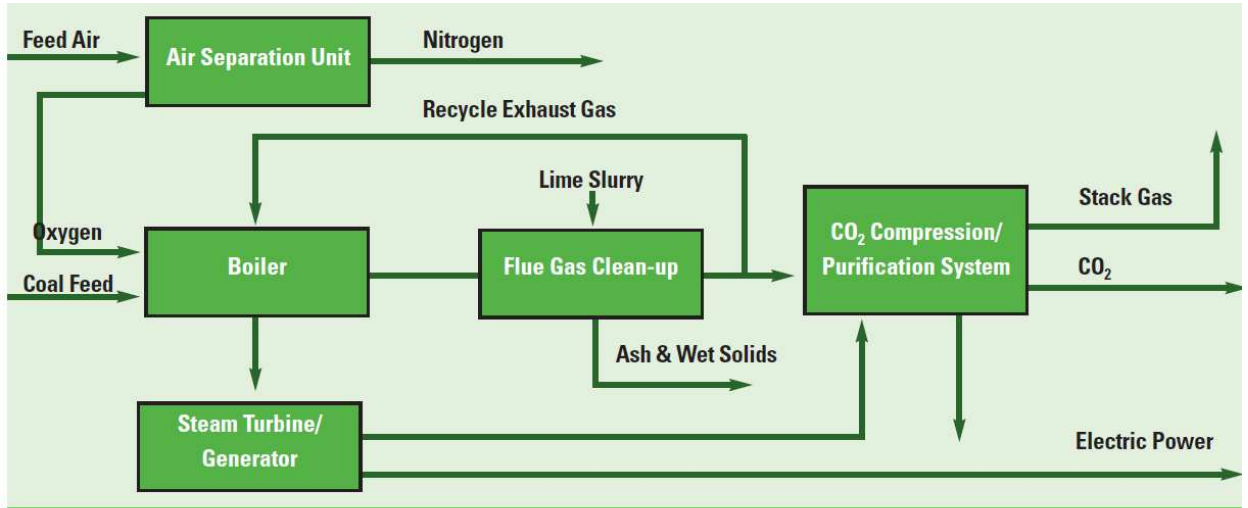

ADAPTED FROM MIT 2007

Fig. 5. Oxy-Fuel Combustion with Capture. 
plants are in the early stages of development with pilot-scale construction currently underway in Europe and in North America as shown in Table 5 (MIT, 2008).

\section{5. $\mathrm{CO}_{2}$ removal from gaseous streams}

There are three incentives to remove $\mathrm{CO}_{2}$ from a process stream:

- $\mathrm{CO}_{2}$ is being removed from a valuable product gas, such as $\mathrm{H}_{2}$, where it is eventually emitted to the atmosphere as a waste by-product.

- $\mathrm{CO}_{2}$ is recovered from a process gas, such as in ethanol production, as a saleable product. However, only a modest fraction of the $\mathrm{CO}_{2}$ produced is marketed as a saleable product, and much of this $\mathrm{CO}_{2}$ finds its way to the atmosphere because the end use does not consume the $\mathrm{CO}_{2}$.

- $\mathrm{CO}_{2}$ is recovered simply to prevent it from being released into the atmosphere, but, this necessarily requires sequestration of the recovered $\mathrm{CO}_{2}$.

Processes to remove $\mathrm{CO}_{2}$ from gas streams vary from simple treatment operations to complex multistep recycle systems.

Most of these processes were developed for natural gas sweetening or $\mathrm{H}_{2}$ recovery from syngas. Recently, interest has built on the capture of $\mathrm{CO}_{2}$ from flue gas, and even landfill gas and coal bed methane gas. In addition, flue gas, coal bed methane and some landfill gases contain $\mathrm{O}_{2}$ that can interfere with certain $\mathrm{CO}_{2}$ separation systems. This complication is generally not present in natural gas, most landfill gas, or $\mathrm{H}_{2}$ systems. Table 6 lists the licensors of $\mathrm{CO}_{2}$ separation processes as of 2004 (Ritter \& Ebner, 2007; Hydrocarbon Processing, 2004).

For these reasons, commercial $\mathrm{CO}_{2}$ gas treatment plants are usually integrated gas processing systems; few are designed simply for $\mathrm{CO}_{2}$ removal. Four different $\mathrm{CO}_{2}$ removal technologies are widely practiced in industry. These are 1) absorption, both chemical and physical, 2) adsorption, 3) membrane separation, and 4) cryogenic processes (Kohl \& Nielsen, 1997). Table 7 shows $\mathrm{CO}_{2}$ separation techniques including the use of them in $\mathrm{CO}_{2}$ capture processes.

\subsection{Absorption processes}

The overwhelming majority of $\mathrm{CO}_{2}$ removal processes in the chemical and petrochemical industries take place by absorption (see Table 6).

The chemical process industries (CPI) remove $\mathrm{CO}_{2}$ to meet process or product requirements (e.g., the production of natural gas, ammonia or ethylene oxide manufacturing). A variety of liquid absorbents are being used to remove $\mathrm{CO}_{2}$ from gas streams.

Absorption processes for $\mathrm{CO}_{2}$ removal generally can be divided into two categories: (a) chemical absorption where the solvent (commonly alkanolamines) chemically reacts with $\mathrm{CO}_{2}$ and (b) physical absorption where the solvent only interacts physically with $\mathrm{CO}_{2}$ (such as methanol in Rectisol Process and glycol ethers in Selexol Process).

In many industrial applications, combinations of physical solvents and reactive absorbents may be used in tandem. The solvents include monoethanolamine (MEA), diethanolamine (DEA), diisopropanolamine (DIPA), methyldiethanolamine (MDEA), and diglycolamine 


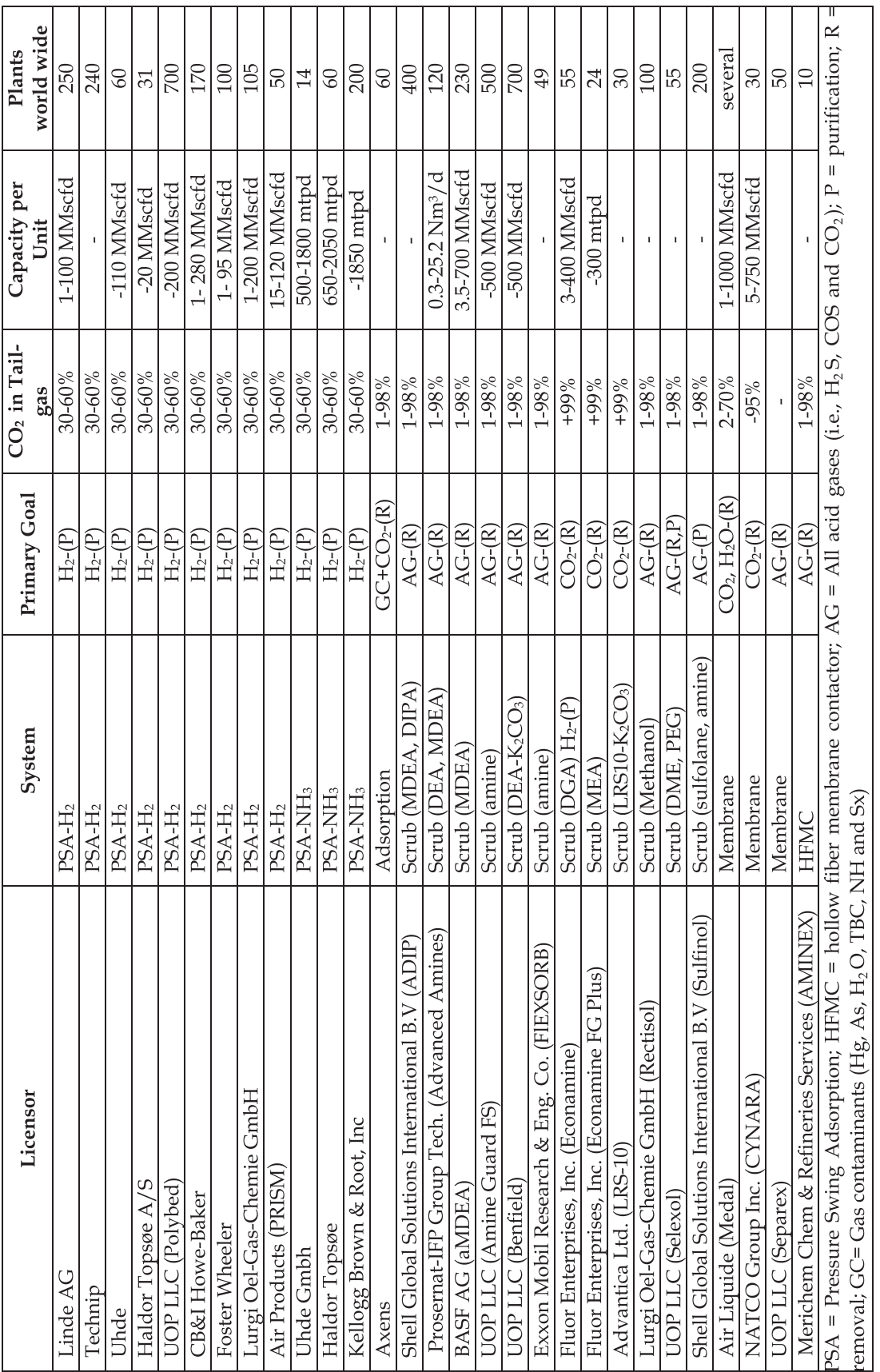

Table 6. Major Licensors of $\mathrm{CO}_{2}$ separation processes from gaseous streams (Hydrocarbon Processing, 2004.) 


\begin{tabular}{|l|c|c|c|}
\hline Separation techniques & Post-combustion & $\begin{array}{c}\text { Oxy fuel- } \\
\text { combustion }\end{array}$ & Pre-combustion \\
\hline $\begin{array}{l}\text { Chemical \& physical } \\
\text { absorption }\end{array}$ & Chemical solvents & - & $\begin{array}{c}\text { Physical solvents } \\
\text { Chemical solvents }\end{array}$ \\
\hline Membrane & $\begin{array}{c}\text { Polymer - Ceramic- } \\
\text { Hybrid - Carbon }\end{array}$ & Polymer & $\begin{array}{c}\text { Polymer- Ceramic } \\
\text { Palladium }\end{array}$ \\
\hline Adsorption & $\begin{array}{c}\text { Zeolites } \\
\text { Active carbons } \\
\text { Molecular sieves }\end{array}$ & $\begin{array}{c}\text { Zeolites - } \\
\text { Activated carbons - } \\
\text { Adsorbents }\left(\mathrm{O}_{2} / \mathrm{N}_{2}\right)\end{array}$ & $\begin{array}{c}\text { Zeolites - Activated } \\
\text { carbons - Aluminum and } \\
\text { silica gel }\end{array}$ \\
\hline Cryogenic & - & Distillation & - \\
\hline
\end{tabular}

Table 7. $\mathrm{CO}_{2}$ separation techniques (IEAGHG, 2011).

(DGA). Ammonia and alkaline salt solutions are also used as absorbents for $\mathrm{CO}_{2}$. Water is used as a $\mathrm{CO}_{2}$ absorbent, but only at high pressures where solubility becomes appreciable. However, in all cases solvent recycling is energy and capital intensive. Among the solvents, MEA has the highest capacity and the lowest molecular weight. It offers the highest removal capacity on either a unit weight or a unit volume basis. When only $\mathrm{CO}_{2}$ is to be removed in large quantities, or when only partial removal is necessary, a hot carbonate solution or one of the physical solvents is economically preferred. MEA has good thermal stability, but reacts irreversibly with $\mathrm{COS}$ and $\mathrm{CS}_{2}$.

DEA has a lower capacity than MEA and it reacts more slowly. Although its reactions with $\mathrm{COS}$ and $\mathrm{CS}_{2}$ are slower, they lead to different products that cause fewer filtration and plugging problems. TEA has been almost completely replaced in sour gas treating because of its low reactivity toward $\mathrm{H}_{2} \mathrm{~S}$. DGA has the same reactivity and capacity as DEA, with a lower vapor pressure and lower evaporation losses. DIPA, which is used in the Sulfinol and Shell Adip processes to treat gas to pipeline specifications, can remove COS and is selective for $\mathrm{H}_{2} \mathrm{~S}$ removal over $\mathrm{CO}_{2}$ removal. MDEA selectively removes $\mathrm{H}_{2} \mathrm{~S}$ in the presence of $\mathrm{CO}_{2}$, has good capacity, good reactivity, and very low vapor pressure. As a result, MDEA is a preferred solvent for gas treating.

Flue gas from combustion processes associated with burners, flaring, incineration, utility boilers, etc. contain significant amounts of $\mathrm{CO}_{2}$. However, as discussed above, this $\mathrm{CO}_{2}$ is generally of low quality because its concentration tends to be low, the flue gas is very hot, and it contains a variety of other gaseous species and particulates that make $\mathrm{CO}_{2}$ recovery difficult and expensive.

Fluor Enterprises Inc. has 24 Econamine FG plants operating worldwide and producing a saleable $\mathrm{CO}_{2}$ product for both the chemical and food industries. Randall Gas Technologies, ABB Lummus Global Inc. has four installations of similar technology operating on coal fired boilers. Two of these plants produce chemical grade $\mathrm{CO}_{2}$ and the other two plants produce food grade $\mathrm{CO}_{2}$. Mitsubishi Heavy Industries Ltd. also has commercialized a flue gas $\mathrm{CO}_{2}$ recovery process, based on their newly developed and proprietary hindered amine solvents (KS-1, KS-2 and KS-3).

\subsection{Adsorption processes}

The adsorption processes include pressure swing adsorption (PSA), temperature swing adsorption (TSA), and hybrid PSA/TSA. Only a few classes of adsorbents and adsorption 
processes are being used to remove $\mathrm{CO}_{2}$ from gas streams. These adsorbents include aluminosilicate zeolite molecular sieves, titanosilicate molecular sieves, and activated carbons. Other classic adsorbents are being used to remove contaminants from $\mathrm{CO}_{2}$ streams destined for commercial use. In this case, the adsorbents include activated carbons for sulfur compounds and trace contaminant removal, silica gels for light hydrocarbon removal, and activated alumina, bauxite, and silica gels for moisture removal. Of the $\mathrm{CO}_{2}$ producing processes listed in Table 6, only $\mathrm{H}_{2}$, syngas, $\mathrm{NH}_{3}$, fermentation ethanol, natural gas, and combustion are beginning to use adsorption processes for removing or purifying $\mathrm{CO}_{2}$.

By-product $\mathrm{CO}_{2}$ from $\mathrm{H}_{2}$ production via methane steam reforming is recovered using PSA in lieu of absorption. The PSA unit offers advantages of improved $\mathrm{H}_{2}$ product purity (9999.99 vol $\% \mathrm{H}_{2}, 100$ ppmv $\mathrm{CH}_{4}, 10-50$ ppmv carbon oxides, and $0.1-1.0 \mathrm{vol} \% \mathrm{~N}_{2}$ ) with capital and operating costs comparable to those of wet scrubbing.

Modern PSA plants for $\mathrm{H}_{2}$ purification generally utilize layered beds containing 3 to 4 adsorbents (e.g., silica gel or alumina for water, activated carbon for $\mathrm{CO}_{2}$, and $5 \mathrm{~A}$ zeolite for $\mathrm{CH}_{4}, \mathrm{CO}$, and $\mathrm{N}_{2}$ removal). Depending on the production volume requirements, from four to sixteen columns are used in tandem. The PSA unit is operated at ambient temperature with a feed pressure ranging between 20 and $60 \mathrm{~atm}$. Hydrogen recovery depends on the desired purity, but ranges between 60 and $90 \%$, with the tail gas (i.e., the desorbed gas containing $\mathrm{H}_{2} \mathrm{O}, \mathrm{N}_{2}, \mathrm{CO}_{2}, \mathrm{CH}_{4}, \mathrm{CO}$, and $\mathrm{H}_{2}$ ) generally being used as fuel for the reformer.

Although PSA systems are increasingly used for $\mathrm{H}_{2}$ recovery, they yield a by-product $\mathrm{CO}_{2}$ stream that is only about $50 \mathrm{vol} \%$ pure. Low purity makes this tail gas stream less attractive as a commercial $\mathrm{CO}_{2}$ source.

As the composition of natural gas varies widely depending on the location of the well (the $\mathrm{CO}_{2}$ concentration in natural gas varies between 3 and $40 \mathrm{vol} \%$; but it could be as high as 80 $\mathrm{vol} \%$ ), and because of the complexity and variability of the composition of natural gas, a train of separation processes, including adsorption, absorption, cryogenic and membrane separation, may be used to process it into pipeline quality methane.

Although the traditional process for removing $\mathrm{CO}_{2}$ has been the amine process, but PSA technology is beginning to supplant some of the absorption technology in natural gas treatment, especially in the so called shut-in natural gas wells that previously contained too much $\mathrm{N}_{2}$ to justify processing.

To remove $\mathrm{CO}_{2}$ from coal bed methane, Engelhard Corporation uses molecular gate adsorption technology with a more traditional PSA mode with compressed feeds ranging in pressure 80-800 psig. Similarly, Axens has commercialized natural gas purification technology, based on alumina and zeolite molecular sieve adsorbents and a TSA regeneration mode. The alumina removes trace and bulk contaminants in the natural gas other than $\mathrm{CO}_{2}$ through both chemisorption and physisorption mechanisms. The zeolite molecular sieve serves to remove $\mathrm{CO}_{2}$ and other contaminants via physisorption. Axens has over 60 installations operating worldwide that treat a variety of natural gas and industrial process streams. Table 8 shows the performance characteristics of some common sorbents for $\mathrm{CO}_{2}$ separation. 


\begin{tabular}{|l|l|l|l|}
\hline \multicolumn{1}{|c|}{ Sorbent } & \multicolumn{1}{|c|}{ Capacity } & \multicolumn{1}{c|}{ Feed composition } & \multicolumn{1}{c|}{ Ref. } \\
\hline Aqueous ammonia & $1.20 \mathrm{~g} \mathrm{CO}_{2} / \mathrm{g} \mathrm{NH}_{3}$ & $15 \mathrm{vol}^{2} \mathrm{CO}_{2}, 85 \mathrm{vol} \% \mathrm{~N}_{2}$ & Yeh et al., 2005 \\
\hline $\begin{array}{l}\text { Aminated } \\
\text { mesoporous silica }\end{array}$ & $\begin{array}{l}0.45-0.6 \mathrm{molCO}_{2} / \mathrm{mol} \\
\text { amine }\end{array}$ & $100 \% \mathrm{CO}_{2}$ & $\begin{array}{l}\text { Knowles } \text { et al., } \\
2005\end{array}$ \\
\hline Aminated SBA-15 & $\begin{array}{l}1528-4188 \mu \mathrm{mol} \mathrm{CO} / \mathrm{g} \\
\text { sorbent }\end{array}$ & $\begin{array}{l}10 \% \mathrm{CO}_{2}, 90 \% \mathrm{He}, \text { with } \\
2 \% \mathrm{H}_{2} \mathrm{O}\end{array}$ & Gray et al., 2005 \\
\hline $\begin{array}{l}\text { PEI-impregnated } \\
\text { MCM-41 }\end{array}$ & $\begin{array}{l}45 \mathrm{ml}(\mathrm{STP}) \mathrm{CO}_{2} / \mathrm{g} \\
\text { adsorbent }\end{array}$ & $\begin{array}{l}15 \% \mathrm{CO}_{2}, 4 \% \mathrm{O}_{2}, 81 \% \\
\mathrm{~N}_{2}\end{array}$ & Xu et al., 2005 \\
\hline $\begin{array}{l}\text { PEI-impregnated } \\
\text { MCM-41 }\end{array}$ & $\begin{array}{l}246 \mathrm{mg} \mathrm{CO} / \mathrm{gPEI} \text { or } 82 \mathrm{mg} \\
\mathrm{CO}_{2} / \mathrm{g} \mathrm{sorbent}^{2}\end{array}$ & $\mathrm{~N} / \mathrm{A}$ & $\begin{array}{l}\text { Xu } \text { et al., 2002; } \\
\text { Song } \text { et al, 2006 }\end{array}$ \\
\hline $\begin{array}{l}\text { Anthracite activated } \\
\text { carbon }\end{array}$ & $65.7 \mathrm{mg} \mathrm{CO} / \mathrm{g}$ adsorbent & $\mathrm{N} / \mathrm{A}$ & $\begin{array}{l}\text { Maroto-Valer } \text { et } \\
\text { al., 2005 }\end{array}$ \\
\hline Lithium silicate & $360 \mathrm{mg} \mathrm{CO} / \mathrm{g}$ sorbent & $100 \% \mathrm{CO}_{2}$ & Kato et al., 2005 \\
\hline
\end{tabular}

Table 8. The $\mathrm{CO}_{2}$ sorbent performance.

\subsection{Membrane processes}

Membrane technology for separating gas streams is attractive for many reasons:

1. It neither requires a separating agent nor involves phase changes.

2. No processing costs associated with regeneration and phase change.

3. The systems involve small footprints compared to other processes.

4. They require low maintenance.

5. They are compact and lightweight and can be positioned either horizontally or vertically, which is especially suitable for retrofitting applications.

6. They are modular units and allow for multi-stage operation.

7. They have linear scale up costs (Takht Ravanchi et al., 2009a; Takht Ravanchi \& Kargari, 2009).

The major drawbacks associated with this technology are the low capacity and poor thermal properties of the current commercial available membranes. Membranes are an appealing option for $\mathrm{CO}_{2}$ separation, mainly because of the inherent permeating properties. $\mathrm{CO}_{2}$ is a fast diffusing gas in many membrane materials, such as glassy and rubbery polymers, molecular sieves, and several other inorganic materials. On the other hand, $\mathrm{CO}_{2}$ also has a relatively high molecular weight and a large quadruple moment, enabling it naturally to adsorb more strongly to or dissolve at much higher concentrations in these membrane materials compared to many other gas species. These properties give rise to very high $\mathrm{CO}_{2}$ permeation rates and selectivities over many other gas species, sometimes even higher than $\mathrm{H}_{2}$ and He. Membrane systems potentially or actually commercialized for gas separations are listed in Table 6 . Of the $\mathrm{CO}_{2}$ producing processes listed, only natural gas production, to a lesser extent landfill gas production, $\mathrm{H}_{2}$, syngas, and $\mathrm{NH}_{3}$ production are beginning to use membrane processes for removing or purifying $\mathrm{CO}_{2}$.

One of the great challenges in membrane-based $\mathrm{CO}_{2}$ separation technology is the lack of membranes with simultaneous high permeability and selectivity. A wide range of selectivity/permeability combinations are provided by different membrane materials, but for gas separation applications, the most permeable polymers at a particular selectivity are of interest, and the highly permeable polymers exhibit moderate to low selectivity values. 
On the other hand, in the application of a membrane with a specific permeability, to meet the desired selectivity using the multi-stage gas separation process is often unavoidable.

Up to now, many studies have been carried out to increase the performance of polymeric membranes. According to these researches, the most important methods for increasing the performance of polymeric membranes are as follows (Sanaeepur et al., 2011a, 2011b; Ebadi et al., 2010, 2011):

1. Incorporation of flexible and polar groups such as amines, carboxyles.

2. Mixing with a carrier (fixed carrier membranes) such as type 1 amino group as a $\mathrm{CO}_{2}$ carrier.

3. Using a soft segment such as poly (dimethyl siloxane).

4. Addition of a compatibilizer such as polystyrene-block-poly (methylmethacrylate) in polymethylmethacrylate/poly methyl ether blends.

5. Polymer blending and interpenetrating polymer networks.

6. Chemical cross-linking and load-bearing network creation via covalent linkages.

7. Structural modification of block copolymers by block copolymerization with a polymer having specific mechanical properties that form a nanostructure, which has physical cross-linkages with favorite properties.

8. Free volume increasing by adding (nano) particles to polymer matrices.

The first commercial cellulose acetate membrane units for $\mathrm{CO}_{2}$ removal from natural gas were implemented only few years after the introduction in 1980 of the first commercial PRISM membrane air separation system developed by Monsanto. By the end of the 1980s companies such as Natco (Cynara), UOP (Separex) and Kvaerner (Grace Membrane Systems) were producing membrane plants for this purpose. A few years later, more selective polyimides and only recently polyaramides were slowly introduced to displace the old cellulose acetate systems. Today, commercial membrane technology for $\mathrm{CO}_{2}$ separation is largely based on glassy polymeric materials (cellulose acetate, polyimides, and polyaramides). Currently, the membrane market devoted to $\mathrm{CO}_{2}$ separation from natural gas is about $20 \%$, which is only $2 \%$ of the total separations market for natural gas. Membranes are used in situations where the produced gas contains high levels of $\mathrm{CO}_{2}$. However, the membranes are very sensitive to exposure to $\mathrm{C} 5+$ hydrocarbons present in wet natural gas streams because these compounds immediately degrades performance and can cause irreversible damage to the membranes. Membranes for large-scale recovery of $\mathrm{CO}_{2}$ from, for example, natural gas for use as a salable product are a relatively recent development. A variety of membranes, including ones with separating layers made of cellulose acetate, polysulfone, and polyimide, are used for this purpose. Air Products and Chemicals and Ube are marketing membrane systems for EOR and landfill gas upgrading, respectively and they have been commercialized for $\mathrm{H}_{2}$ purification in reforming processes. For example, membrane processes, such as the POLYSEP membrane systems developed by UOP and the PRISM membrane systems developed by Monsanto and now sold by Air Products and Chemicals recover $\mathrm{H}_{2}$ from various refinery, petrochemical and chemical process streams. Both are based on polymeric asymmetric membrane materials composed of a single polymer or layers of at least two different polymers, with the active polymer layer being a polyimide. The PRISM system is based on a hollow fiber design and POLYSEP is a spiral-wound, sheet-type contactor. Both are used to recover $\mathrm{H}_{2}$ from refinery streams at purities ranging from 70 to $99 \mathrm{vol} \%$ and with recoveries ranging from 70 to $95 \%$. Relatively 
pure $\mathrm{H}_{2}$ containing a very low concentration of $\mathrm{CO}_{2}$ leaves these units in the low pressure permeate stream. This stream can be sent to a methanator for $\mathrm{CO}_{2}$ removal and further purification. The high-pressure retentate stream, consisting of $\mathrm{H}_{2}$ and $\mathrm{CO}_{2}$ with low concentrations of $\mathrm{CO}$ and $\mathrm{CH}_{4}$, can be used as fuel.

Figure 6 shows the currently status of the developed membranes for separation of $\mathrm{CO}_{2}$ from $\mathrm{N}_{2}$ streams as the selectivity (alpha) versus permeability $(\mathrm{P})$.

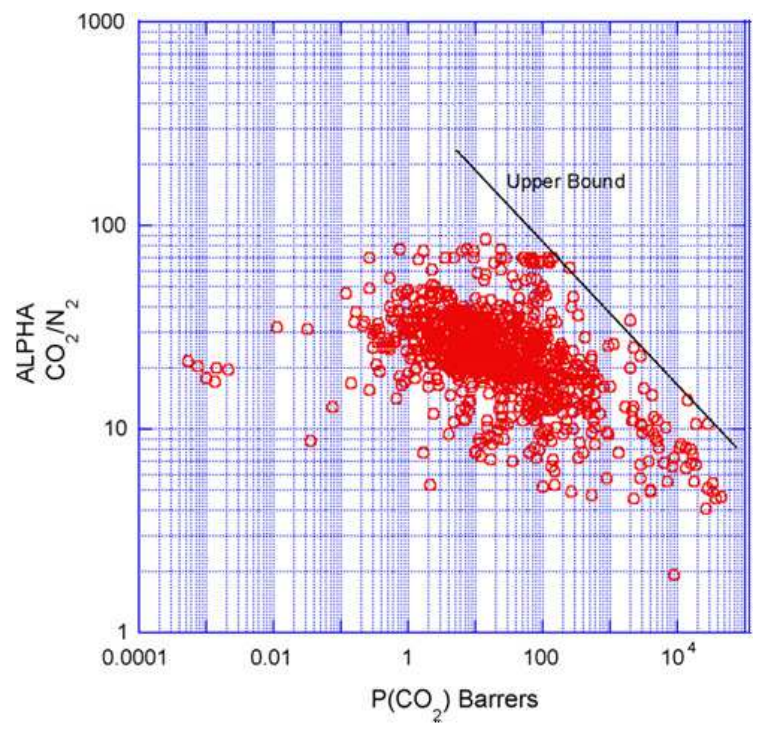

Fig. 6. Upper bound correlation for $\mathrm{CO}_{2} / \mathrm{N}_{2}$ separation (Robeson, 2008).

Another attractive membrane system is so called "Liquid Membrane" (LM) which have been found many applications in chemical engineering, medicinal and environmental processes (Kaghazchi et al., 2006, 2009; Kargari et al., 2002, 2003a, 2003b, 2003c, 2003d, 2004a, 2004b, 2004c, 2004d, 2004e, 2005a, 2005b, 2006a, 2006b, 2006c ; Mohammadi et al., 2008; Nabieyan et al., 2007; Rezaei et al., 2004).

Separation of gases by LM is a new field in separation science and technology. Separation of olefin/paraffin gases are very attractive and cost effective (Takht Ravanchi, 2008a, 2008b, 2008c, 2008d, 2009a, 2009b, 2009c, 2010a, 2010b, 2010c). $\mathrm{CO}_{2}$ removal from gas streams especially natural gas is important for increase the heating value of the natural gas and limiting the $\mathrm{CO}_{2}$ emission in the combustion systems (Heydari Gorji, 2009a, 2009b).

The advantage of the LM over solid (organic or inorganic) membranes are ease of operational conditions and very higher selectivities (in the order of several hundreds), but the instability problems of the LM have limited the industrial applications of this attractive technology.

\subsection{Cryogenic liquefaction processes}

Recovery of $\mathrm{CO}_{2}$ by cold liquefaction has the advantage of enabling the direct production of very pure liquid $\mathrm{CO}_{2}$, which can be readily transported. The disadvantages associated with 
the cryogenic separation of $\mathrm{CO}_{2}$ are the amount of energy required in refrigeration, particularly in dilute gas streams, and the requirement to remove gases, such as water and heavy hydrocarbons, that tend to freeze and block the heat exchangers.

Liquefaction technology for $\mathrm{CO}_{2}$ recovery is still incipient. Cryogenic $\mathrm{CO}_{2}$ recovery is typically limited to streams that contain high concentrations of $\mathrm{CO}_{2}$ (more than $50 \mathrm{vol} \%$ ), but with a preferred concentration of $>90 \mathrm{vol} \%$. It is not considered to be a viable $\mathrm{CO}_{2}$ capture technology for streams that contain low concentrations of $\mathrm{CO}_{2}$, which includes most of the industrial sources of $\mathrm{CO}_{2}$ emissions. Cryogenic separation of $\mathrm{CO}_{2}$ is most applicable to high-pressure gas streams, like those available in pre-combustion and oxyfuel combustion processes. Cryogenic $\mathrm{CO}_{2}$ recovery is increasingly being used commercially for purification of $\mathrm{CO}_{2}$ from streams that already have high $\mathrm{CO}_{2}$ concentrations (typically $>90 \%$ ). Of the $\mathrm{CO}_{2}$ producing processes listed in Table 6, only ethanol production and $\mathrm{H}_{2}$, syngas, and $\mathrm{NH}_{3}$ production utilize cryogenic processes for removing or purifying $\mathrm{CO}_{2}$.

Currently, Costain Oil, Gas \& Process Ltd. has commercialized a $\mathrm{CO}_{2}$ liquefaction process with around seven units installed worldwide. The process is assisted by membrane technology to treat streams with $\mathrm{CO}_{2}$ fractions greater than 90 vol.\%

Recently, Fluor Enterprises Inc. also developed a $\mathrm{CO}_{2}$ liquefaction process called $\mathrm{CO}_{2}$ LDSEP. This technology exploits liquefaction to separate $\mathrm{CO}_{2}$ from $\mathrm{H}_{2}$ and other gases in the tail gas of a $\mathrm{H}_{2}$ purification PSA unit. Table 9 demonstrates the $\mathrm{CO}_{2}$ capture technologies advantages and challenges.

\section{6. $\mathrm{CO}_{2}$ conversion, utilization and fixation}

One way to mitigate carbon dioxide emission is its conversion and fixation to value-added products. The main processes for carbon dioxide conversion and fixation in chemical industries are:
a. Hydrogenation
b. Oxidative Dehydrogenation
c. Oxidative Coupling of Methane
d. Dry Reforming of Methane

$\mathrm{CO}_{2}$ is not just a greenhouse gas, but also an important source of carbon for making organic chemicals, materials and carbohydrates (e.g., foods). As will be discussed below, various chemicals, materials, and fuels can be synthesized using $\mathrm{CO}_{2}$, which should be a sustainable way in the long term when renewable sources of energy such as solar energy is used as energy input for the chemical processing.

Some general guidelines for developing technologies for $\mathrm{CO}_{2}$ conversion and utilization can be summarized as below:

- Select concentrated $\mathrm{CO}_{2}$ sources for $\mathrm{CO}_{2}$ capture and/or utilization; aim for onsite/nearby uses if possible.

- Use $\mathrm{CO}_{2}$ to replace a hazardous or less-effective substance in existing chemical processes for making products with significant volumes.

- Use renewable sources of energy or 'waste' energy for $\mathrm{CO}_{2}$ conversion and utilization whenever possible. 


\begin{tabular}{|c|c|c|c|c|c|}
\hline & 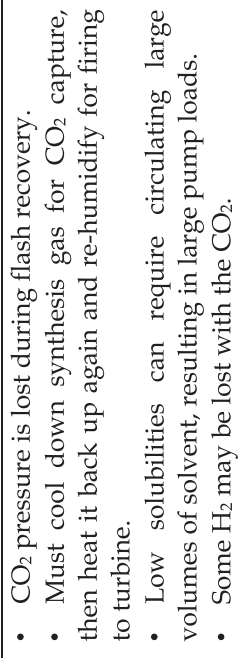 & 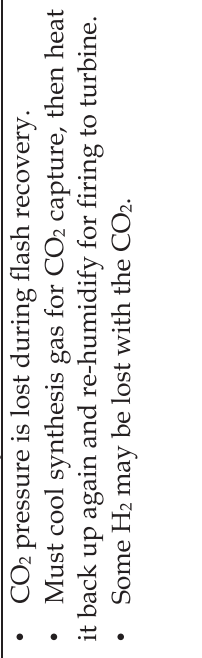 & 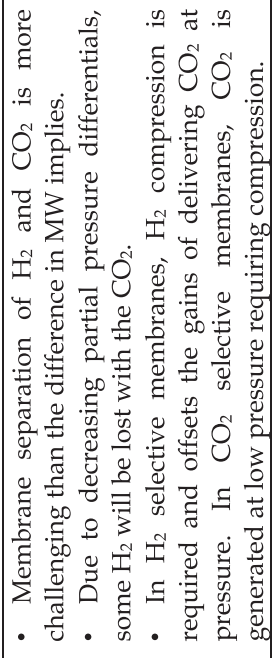 & 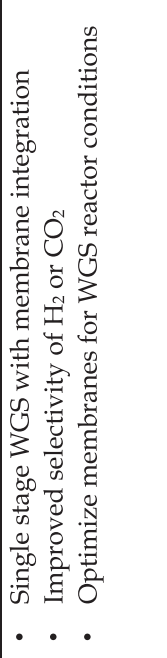 & 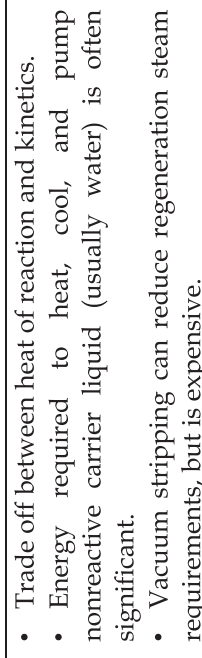 \\
\hline 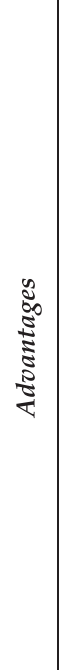 & 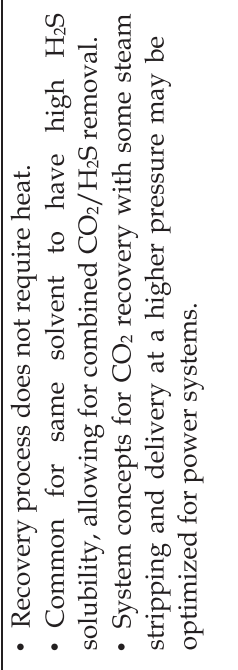 & 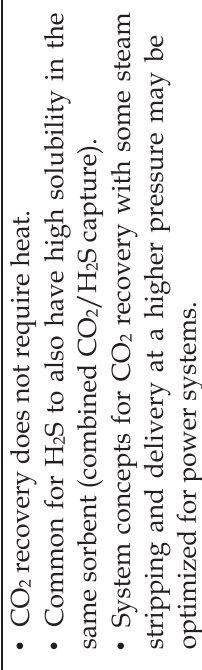 & 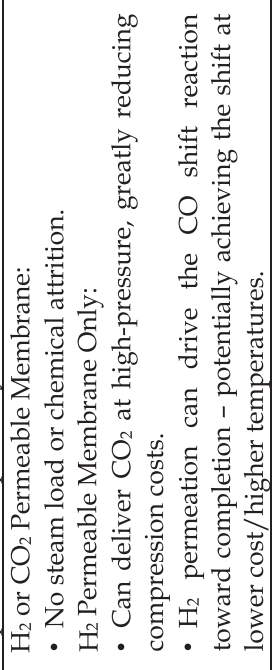 & 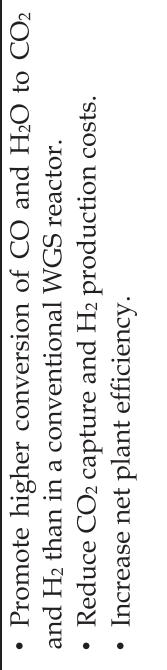 & 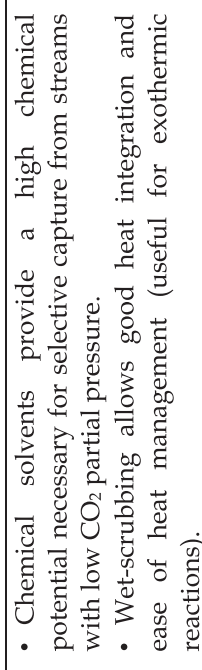 \\
\hline 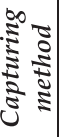 & $\begin{array}{l}\Lambda \text { [OS } \\
! \mathrm{S} \kappa \mathrm{Y}_{\mathrm{d}}\end{array}$ & $\begin{array}{l}\text { ұuaquos } \\
\text { p!̣os }\end{array}$ & әиеxquәW ${ }^{2} \mathrm{O} /{ }^{2} \mathrm{H}$ & 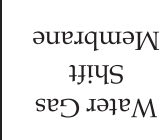 & ұ૫ә \\
\hline $\begin{array}{c}\frac{1}{5} \\
\frac{3}{5} \\
0 \\
0\end{array}$ & \multicolumn{4}{|c|}{ uọ̣snquo $\supset$-əد, } & $\begin{array}{c}\text { uọ̣snquojo } \\
-7 \mathrm{sod}_{\mathrm{d}}\end{array}$ \\
\hline
\end{tabular}




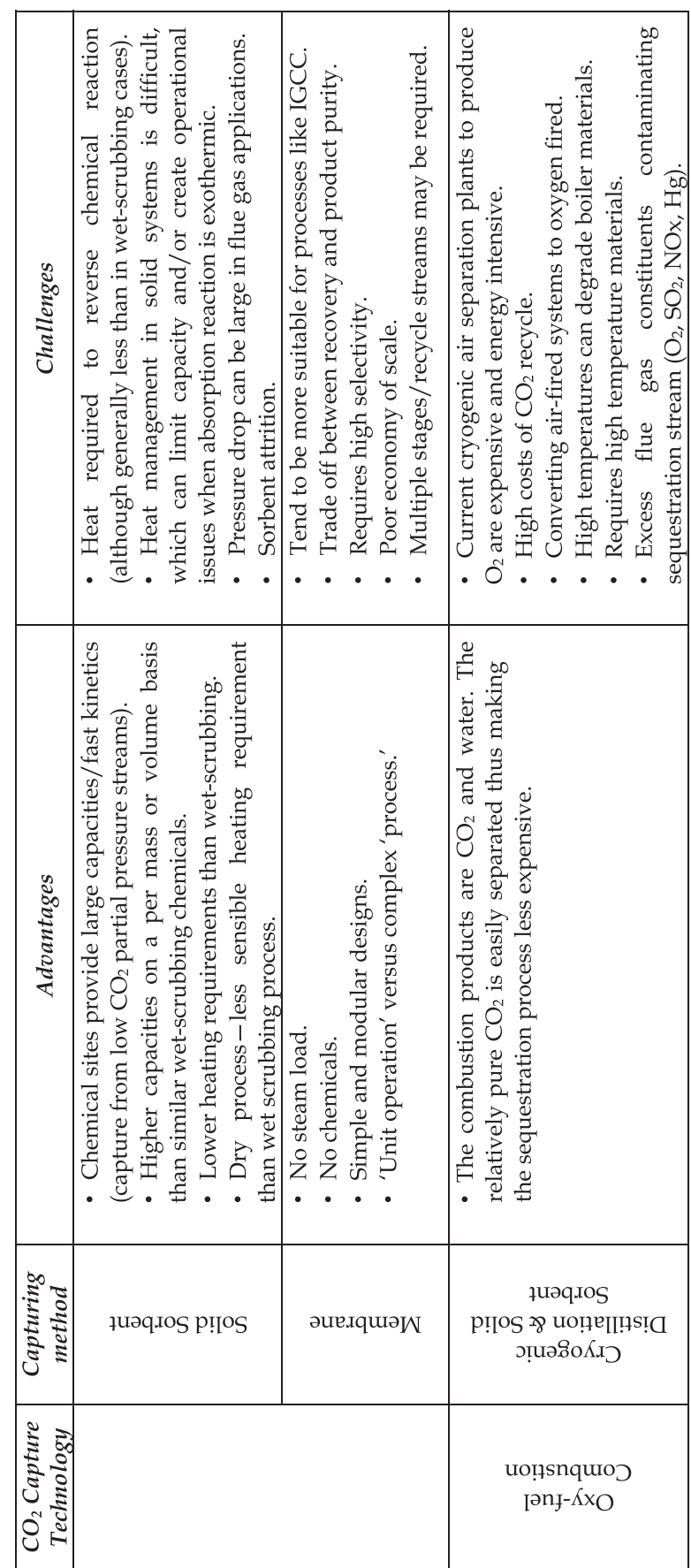

Table 9. $\mathrm{CO}_{2}$ capture technologies advantages and challenges (DOE/NETL 2010) 
- Convert $\mathrm{CO}_{2}$ along with other co-reactants into chemical products that are industrially useful at significant scale.

- Fix $\mathrm{CO}_{2}$ into environmentally benign organic chemicals, polymer materials or inorganic materials.

- Electric power generation with more efficient $\mathrm{CO}_{2}$ capture and conversion or utilization.

- Take value-added approaches for $\mathrm{CO}_{2}$ sequestration coupled with utilization.

$\mathrm{CO}_{2}$ is used as refrigerant for food preservation, beverage carbonation agent, supercritical solvent, inert medium (such as fire extinguisher), pressurizing agent, chemical reactant (urea, etc.), neutralizing agent, and as gas for greenhouses.

Solid $\mathrm{CO}_{2}$ (dry ice) has a greater refrigeration effect than water ice. Dry ice is also usually much colder than water ice, and the dry ice sublimates to a gas as it absorbs heat. It should be noted that the use of $\mathrm{CO}_{2}$ for refrigeration does not directly contribute to reduction of $\mathrm{CO}_{2}$ emissions.

There exist some chemical processes for $\mathrm{CO}_{2}$ conversion in chemical industry, for which synthesis of urea from ammonia and $\mathrm{CO}_{2}$ (Eq. (1)) and the production of salicylic acid from phenol and $\mathrm{CO}_{2}$ (Eq. (2)) are representative examples. Urea is used for making various polymer materials, for producing fertilizers and in organic chemical industry. It is a preferred solid nitrogen fertilizer because of its high nitrogen content (46\%). As an example of the usefulness of salicylic acid, acetyl salicylic acid is used for making Aspirin, a widely used common medicine.

$$
\begin{gathered}
\mathrm{CO}_{2}+2 \mathrm{NH}_{3} \rightarrow \mathrm{H}_{2} \mathrm{~N}-\mathrm{CO}-\mathrm{NH}_{2} \\
\mathrm{C}_{6} \mathrm{H}_{5}-\mathrm{OH}+\mathrm{CO}_{2} \rightarrow \mathrm{C}_{6} \mathrm{H}_{5}(\mathrm{OH}) \mathrm{COOH}
\end{gathered}
$$

Supercritical $\mathrm{CO}_{2}$ can be used as either a solvent for separation or as a medium for chemical reaction, or as both a solvent and a reactant. The use of supercritical $\mathrm{CO}_{2}\left(\mathrm{SC}-\mathrm{CO}_{2}\right)$ allows contaminant free supercritical extraction of various substances ranging from beverage materials (such as caffeine from coffee bean), foods (such as excess oil from fried potato chips), and organic and inorganic functional materials, to herbs and pharmaceuticals. It is also possible to use $\mathrm{SC}-\mathrm{CO}_{2}$ to remove pollutants such as PAHs from waste sludge and contaminated soils and toxics on activated carbon adsorbent (Akgerman et al. 1992).

The dissociation of $\mathrm{CO}_{2}$ on catalyst surface could produce active oxygen species. Some heterogeneous chemical reactions can benefit from using $\mathrm{CO}_{2}$ as a mild oxidant, or as a selective source of "oxygen" atoms. For example, the use of $\mathrm{CO}_{2}$ has been found to be beneficial for selective dehydrogenation of ethylbenzene to form styrene, and for dehydrogenation of lower alkanes such as ethane, propane and butane to form ethylene, propylene, and butene, respectively. Some recent studies on heterogeneous catalytic conversion using $\mathrm{CO}_{2}$ as an oxidant have been discussed in several recent reviews (Song et al, 2002; Park et al, 2001). If renewable sources or waste sources of energy are used, recycling of $\mathrm{CO}_{2}$ as carbon source for chemicals and fuels should be considered for applications where $\mathrm{CO}_{2}$ can be used that have desired environmental benefits. $\mathrm{CO}_{2}$ recycling would also make sense if such an option can indeed lead to less consumption of carbon-based fossil resources without producing more $\mathrm{CO}_{2}$ from the whole system. Conversion of $\mathrm{CO}_{2}$ to $\mathrm{C} 1$ to $\mathrm{C} 10$ hydrocarbon fuels via methanol has also been reported (Nam et al, 1999). There has been 
some reported effort on direct synthesis of aromatics from hydrogenation of $\mathrm{CO}_{2}$ using hybrid catalysts composed of iron catalysts and HZSM-5 zeolite (Kuei and Lee, 1991). Related to the methanol synthesis and Fischer- Tropsch synthesis is the recently proposed tri-reforming process for conversion of $\mathrm{CO}_{2}$ in flue gas or in $\mathrm{CO}_{2}$-rich natural gas without $\mathrm{CO}_{2}$ pre-separation to produce synthesis gas $\left(\mathrm{CO}+\mathrm{H}_{2}\right)$ with desired $\mathrm{H}_{2} / \mathrm{CO}$ ratios of 1.5-2.0 (Song \& Pan 2004). For the $\mathrm{CO}_{2}$ conversion to methanol using $\mathrm{H}_{2}$, it should be noted that $\mathrm{H}_{2}$ is currently produced by reforming of hydrocarbons which is an energy-intensive process and accompanied by $\mathrm{CO}_{2}$ formation both from the conversion process and from the combustion of the fuels which is used to provide the process heat (Armor, 2000). Therefore, methanol synthesis using $\mathrm{CO}_{2}$ does not contribute to $\mathrm{CO}_{2}$ reduction unless $\mathrm{H}_{2}$ is produced by using renewable energy or process waste energy or nuclear energy. BTX hydrocarbons (benzene, toluene, and xylenes) are important sources of petrochemicals for gasoline and other feed-stocks. Aromatization of lower alkanes is an interest in industry, and many efforts have been made in this area. The transformation of $\mathrm{CH}_{4}$ to aromatics is thermodynamically more favorable than the transformation of $\mathrm{CH}_{4}$ to $\mathrm{C}_{2} \mathrm{H}_{6}$, and extensive efforts have also been devoted to the direct conversion along this line in heterogeneous catalysis. To achieve the high activity and stability in methane dehydroaromatization, novel approaches to reduce carbon deposition are being made. The co-feeding of some oxidants $\left(\mathrm{NO}, \mathrm{O}_{2}, \mathrm{CO}\right.$, and $\mathrm{CO}_{2}$ ) with $\mathrm{CH}_{4}$ has been proposed. $\mathrm{CO}_{2}$ is an acidic oxide, when it is dissolved in water, either as bicarbonate or carbonate (Ayers, 1988), it is slightly acidic. This weak acidity can be used in neutralization processes e.g., in purification of water from swimming pools. Due to its weak acidity, the $\mathrm{pH}$ value it can reach is limited (from $\mathrm{pH}$ of 12-13 to 6-9). Carbon dioxide can react in different ways with a large variety of compounds. The products that may be obtained are including, e.g., organic carbonates, (amino-) acids, esters, lactones, amino alcohols, carbamates, urea derivatives, and various polymers or copolymers. The limited number of publications in this research area shows that this new territory is still to be exploited. Some of these products are of great technical interest. The major reactions and their products are listed in Table 10. There are both natural and artificial ways to capture or fix the carbon to avoid or delay emission into the atmosphere, such as

\begin{tabular}{|l|l|l|l|}
\hline reactants & products with $\mathrm{CO}_{2}$ & reactants & products with $\mathrm{CO}_{2}$ \\
\hline alkane & $\begin{array}{l}\text { syngas, acids, esters, } \\
\text { lactones }\end{array}$ & $\begin{array}{l}\text { Substituted } \\
\text { hydrocarbon }\end{array}$ & $\begin{array}{l}\text { acids, esters, lactones, } \\
\text { polycarbonates }\end{array}$ \\
\hline cycloalkane & acids, esters, lactones & alkyne & $\begin{array}{l}\text { lactones, unsaturated } \\
\text { organic carbonates }\end{array}$ \\
\hline $\begin{array}{l}\text { active-H } \\
\text { compound }\end{array}$ & acids, esters, lactones & epoxide & $\begin{array}{l}\text { carbonates, (co)polymers } \\
\text { (polycarbonates) }\end{array}$ \\
\hline monoalkene & acids, esters, lactones & $\mathrm{NH}_{3}$ and amine & $\begin{array}{l}\text { symmetrical ureas, } \\
\text { aminoacids, (co)polymers }\end{array}$ \\
\hline diene & acids, esters, lactones & diamine & $\begin{array}{l}\text { ureas, carbamates, } \\
\text { (co)polymers (polyureas) }\end{array}$ \\
\hline cycloalkene & $\begin{array}{l}\text { acids, esters, lactones, } \\
\text { (co)polymers }\end{array}$ & imines & $\begin{array}{l}\text { carbamates, (co)polymers } \\
\text { (urethane) }\end{array}$ \\
\hline a Allenes and 1,3-dienes; ${ }^{\mathrm{b}}$ With longer C-C chain than the original monomer; ${ }^{\mathrm{c} \text { Dihalogen substituted }}$ \\
\hline
\end{tabular}

Table 10. Reactants and their products in $\mathrm{CO}_{2}$ reactions 
forestation, ocean fertilization, photosynthesis, mineral carbonation, In-situ $\mathrm{CO}_{2}$ capture and hydrate. Interested researcher is referred to (Yamasaki A, 2003; Stewart C, Hessami M, 2005; Maroto-Valer et al., 2005; Druckenmiller and Maroto-Valer, 2005; Liu et al., 2005; Stolaroff et al., 2005) for further details in this subject.

\section{Conclusion}

$\mathrm{CO}_{2}$ emission along with its global warming is one of the most important and emergency problem threatens the living on the earth. Although some governmental laws and protocols have limited the emissions, but the emission rates are so high that the accumulation of $\mathrm{CO}_{2}$ have caused the global climate change. Carbon based fossil fuels have the correct energy concentration and most probably will continue to be the main energy source in the shortmedium term but it is necessary to control the $\mathrm{CO}_{2}$ emission to the atmosphere. The future trends for controlling $\mathrm{CO}_{2}$ emission and accumulation in the atmosphere should forced on:

1. Reducing fossil fuel use or switching to less $\mathrm{CO}_{2}$ intense fuels such as biofuls and $\mathrm{H}_{2}$.

2. Using more efficient energy systems.

3. Increasing the contribution of alternative energies such as solar, wind, etc. in processes.

4. Developing and improving the capture and separation technologies that are economically sound and effective under the operating conditions of $\mathrm{CO}_{2}$-producing processes.

5. Developing and improving $\mathrm{CO}_{2}$ storage including terrestrial biomass, deep oceans, saline aquifers, and minerals.

6. Utilizing and sequestering $\mathrm{CO}_{2}$ by emphasis on fostering and chemical processes.

\section{References}

Akgerman, C. E.; Ghoreishi, S.M. (1992). Supercritical extraction of hexachlorobenzene from soil, Ind. Eng. Chem. Res., Vol.31, No.1, pp.333-339

Armor, J.N. (2000). Catalytic fixation of $\mathrm{CO}_{2}, \mathrm{CO}_{2}$ purity, energy, and the environment, $\mathrm{Am}$. Chem. Soc. Div. Petrol. Chem. Prepr., Vol.45, No.1, pp.141-142

Audus, H.; Kaarstad O. \& Kowal M. (1996). Decarbonisation of fossil fuels: hydrogen as an energy carrier. Proc 11th World Hydrogen Energy Conference, Int. Assoc. of Hydrogen Energy, published by Schon and Wetzel, Frankfurt, Germany

Ayers, W. M. (Ed.) (1988). Catalytic Activation of Carbon Dioxide; ACS Symposium Series 363; American Chemical Society: New York

Climate Change: Forests and Carbon Sequestration (2007). Temperate Forest Foundation Vol.16, No.2

DOE/NETL 2010, Carbon Dioxide Capture and Storage RD\&D Roadmap, December 2010, http://www.netl.doe.gov/technologies/carbon_seq/refshelf/CCSRoadmap.pdf

Druckenmiller M.L. \& Maroto-Valer M.M.; (2005). Carbon sequestration using brine of adjusted $\mathrm{pH}$ to form mineral carbonates. Fuel Processing Technology, 86: 1599-1614

Ebadi, A.; Sanaeepur, H.; Kargari, A. \& Moghadassi, A.R. (2011). Direct determination of concentration-dependent diffusion coefficient in polymeric membranes based on the Frisch method, Sep. Puri. Technol., DOI: 10.1016/j.seppur.2011.08.031. 
Ebadi, A.; Sanaeepur, H.; Moghadassi, A.R.; Kargari, A.; Ghanbari, D. \& Sheikhi, Z. (2010). Modification of ABS membrane by PEG for capturing carbon dioxide from $\mathrm{CO}_{2} / \mathrm{N}_{2}$ streams, Sep. Sci. Technol., 45, 1385-1394.

Freund, P. and J. Gale, (2001). Greenhouse gas abatement in energy intensive industries, Proceedings of the $5^{\text {th }}$ International Conference of Greenhouse Gas Control Technologies, Cairns, Australia, 2001. CSIRO Publishing

Gray, M.L., et al. (2005). Improved immobilized carbon dioxide capture sorbents. Fuel Processing Technology, 86(14-15): 1449-1455

Henriks, C.A., et al., (1999). Emission reduction of greenhouse gases from the cement industry, Greenhouse Gas Control Technologies, Proceedings of the $4^{\text {th }}$ International Conference of Greenhouse Gas Control Technologies, Interlaken, Switzerland, Sept. (1998), Elsevier Science Ltd, Oxford, UK

Heydari Gorji, A.; Kaghazchi, T. \& Kargari, A. (2009a). Selective Removal of Carbon Dioxide from Wet $\mathrm{CO}_{2} / \mathrm{H}_{2}$ Mixtures via Facilitated Transport Membranes containing Amine Blends as Carriers, Chem. Eng. Technol. Vol. 32, No. 1, pp. 120-128

Heydari Gorji., A.; Kaghazchi, T. \& Kargari, A. (2009b) Analytical solution of competitive facilitated transport of acid gases through liquid membranes, Desalination, Vol. 235, pp. $245-263$

Hydrocarbon Processing (2004). Gas Processes 2004, Gulf Publishing Co.

IEA (2003). $\mathrm{CO}_{2}$ emissions from fuel combustion 1997-2001, IEA/OECD, Paris, France

IEAGHG (2011). Potential for Biomass and Carbon Dioxide Capture and Storage

IEAW (2010), $\mathrm{CO}_{2}$ Emissions from Fuel Combustion - Highlights ,International Energy Agency website, retrieved 2010-10-06

IPCC (2006). Special Report on Carbon Dioxide Capture and Storage, Edward S. Rubin, Carnegie Mellon University, Pittsburgh, Pennsylvania, USA, Presentation to the RITE International Workshop on $\mathrm{CO}_{2}$ Geological Storage, Tokyo, Japan February 20

Kaghazchi T.; Kargari, A.; Yegani, R. \& Zare, A. (2006). Emulsion liquid membrane pertraction of L-lysine from dilute aqueous solutions by D2EHPA mobile carrier, Desalination, Vol. 190, pp. 161-171

Kaghazchi, T.; Takht Ravanchi, M.; Kargari, A. \& Heydari Gorji, A. (2009) Application of Liquid Membrane in Separation Processes, J. Sep. Sci. Eng., Vol.1, No. 1, pp. 81-89

Kargari A.; et al., (2003d). Recovery of Phenol from High Concentration Phenolic Wastewater by Emulsion Liquid Membrane Technology, $8^{\text {th }}$ Iranian National Chemical Engineering Conference, Mashhad, October 2003, Iran

Kargari A.; Kaghazchi, T. \& Soleimani, M. (2003a). Application of Emulsion Liquid Membrane in the Extraction of Valuable Metals from Aqueous Solutions, $4^{\text {th }}$ European Congress of Chemical Engineering, Granada, September 2003, Spain

Kargari A.; Kaghazchi, T. \& Soleimani, M. (2003b). Role of Emulsifier in the Extraction of Gold (III) Ions from Aqueous Solutions Using Emulsion Liquid Membrane Technique, Permea2003 Conference, Tatranske Matliare, September 2003, Slovakia

Kargari A.; Kaghazchi, T. \& Soleimani, M. (2003c). Extraction of gold (III) ions from aqueous solutions using surfactant Liquid Membrane, $8^{\text {th }}$ Iranian National Chemical Engineering Conference, Mashhad, October 2003, Iran

Kargari A.; Kaghazchi, T. \& Soleimani, M. (2004a). Role of Emulsifier in the Extraction of Gold (III) Ions from Aqueous Solutions Using Emulsion Liquid Membrane Technique, Desalination, Vol. 162, pp. 237-247 
Kargari A.; Kaghazchi, T. \& Soleimani, M. (2004b) Mass transfer investigation of liquid membrane transport of gold (III) by methyl iso-butyl ketone mobile carrier, J. Chem. Eng. E Tech., Vol. 27, pp. 1014-1018

Kargari A.; Kaghazchi, T. \& Soleimani, M. (2004c). Mass transfer investigation of liquid membrane transport of gold (III) by methyl iso-butyl ketone mobile carrier, Chisa Conference, Praha, August 2004, Czech Republic

Kargari A.; Kaghazchi, T. \& Soleimani, M. (2005a). Extraction of gold (III) ions from aqueous solutions using emulsion liquid membrane technique, International Solvent Extraction Conference (ISEC 2005), The People's Republic of China, September 2005, China

Kargari A.; Kaghazchi, T. \& Soleimani, M. (2006a). Mathematical modeling of emulsion liquid membrane pertraction of gold (III) from aqueous solutions, J. Memb. Sci. Vol. 27, pp. 380-388

Kargari A.; Kaghazchi, T.; Kamrani, G. \& Forouhar, T. (2005b). Pertraction of phenol from aqueous wastes using emulsion liquid membrane system, FILTECH Conference, Wiesbaden, October 2005, Germany

Kargari A.; Kaghazchi, T.; Mardangahi, B. \& Soleimani, M. (2006b). Experimental and modeling of selective separation of gold (III) ions from aqueous solutions by emulsion liquid membrane system, J. Memb. Sci. Vol. 279, pp. 389-393

Kargari A.; Kaghazchi, T.; Sohrabi, M. \& Soleimani, M. (2006c). Application of Experimental Design to Emulsion Liquid Membrane Pertraction of Gold (III) Ions from Aqueous Solutions, Iranian Journal of Chemical Engineering, Vol. 3, No. 1, pp. 76-90

Kargari A.; Kaghazchi, T.; Sohrabi, M. \& Soleimani, M. (2004d). Batch Extraction of Gold (III) Ions from Aqueous Solutions Using Emulsion Liquid Membrane via Facilitated Carrier Transport, J. Membr. Sci., Vol. 233, pp. 1-10

Kargari A.; Kaghazchi, T.; Sohrabi, M. \& Soleimani, M. (2004e). Emulsion liquid membrane pertraction of gold (III) ion from aqueous solutions, 9th Iranian Chemical Engineering Congress, Iran University of Science and Technology, November 2004

Kargari, A.; Kaghazchi, T.; Mohagheghi, E. \& Mirzaei, P. (2002). Application of Emulsion Liquid Membrane for treatment of phenolic wastewaters, Proceedings of $7^{\text {th }}$ Iranian Congress of Chemical Engineering, pp. 310-316, Tehran University, October 2002, Iran

Kato M, et al., (2005). Novel CO2 absorbents using lithium containing oxide. International Journal of Applied Ceramic Technology, 2(6): 467-475

Knowles G P, et al., (2005). Aminopropyl-functionalized mesoporous silicas as CO2 adsorbents. Fuel Processing Technology, 86: 1435-1448

Kohl, A.L. \& Nielsen, R.B. (1997). Gas Purification, 4th ed., Gulf Publishing Company, Houston, Texas

Kuei C.K., M.D. Lee, (1991). Hydrogenation of carbon-dioxide by hybrid catalysts, direct synthesis of aromatics from carbon-dioxide and hydrogen, Can. J. Chem. Eng. 69 (1), 347-354

Liu N, et al., (2005). Biomimetic sequestration of $\mathrm{CO}_{2}$ in carbonate form: Role of produced waters and other brines. Fuel Processing Technology, 86: 1615-1625

Lotz, M. \& Brent, A.C. (2008). A review of carbon dioxide capture and sequestration and the Kyoto Protocol's clean development mechanism and prospects for Southern Africa. Journal of Energy in Southern Africa, Vol.19, No.1, pp.13-24 
Mahmoudkhani M., D.W. Keith, (2009). Low-energy sodium hydroxide recovery for CO2 capture from atmospheric air-Thermodynamic analysis, International Journal of Greenhouse Gas Control, 3, 376-384

Maroto-Valer M.M.; Tang Z.; Zhang Y.; (2005). $\mathrm{CO}_{2}$ capture by activated and impregnated anthracites. Fuel Processing Technology, 86(14-15): 1487-1502

MIT 2008-Massachusetts Institute of Technology (2008). Carbon Capture \& Sequestration Technologies Program. Carbon Dioxide Capture and Storage Projects. http://sequestration.mit.edu/tools/projects/index.html

Moghadassi, A.; Ebadi, A. \& Kargari, A. (2009). Development of the polymeric blend membrane for $\mathrm{CO}_{2} / \mathrm{N}_{2}$ separation, The $6^{\text {th }}$ International Chemical Engineering Congress (IChEC 2009), Kish Island, Iran

Mohammadi S.; Kaghazchi, T. \& Kargari, A. (2008). A model for metal ion pertraction through supported liquid membrane, Desalination, Vol. 219, pp. 324-334

Nabieyan B.; Kaghazchi, T.; Kargari, A.; Mahmoudian, A. \& Soleimani, M. (2007). Benchscale simultaneous extraction and stripping of iodine using bulk liquid membrane system, Desalination, Vol. 214, pp. 167-176

Nam S.S., H. Kim, G. Kishan, M.J. Choi, K.W. Lee (2001). Catalytic conversion of carbon dioxide into hydrocarbons over iron supported on alkali ion exchanged Y-zeolite catalysts, Appl. Catal. A: Gen. 179 (1-2) (1999) 155-163

Park S.E., J.S. Yoo, J.-S. Chang, K.Y. Lee, M.S. Park, Heterogeneous catalytic activation of carbon dioxide as an oxidant, Am. Chem. Soc. Div. Fuel Chem. Prepr. 46 (1), 115-118

Rezaei M.; Mehrabani, A.; Kaghazchi, T. \& Kargari, A. (2004). Extraction of chromium ion from industrial wastewaters using bulk liquid membrane, 9th Iranian Chemical Engineering Congress, Iran University of Science and Technology, November 2004

Ritter J.A.; A.D. Ebner (2007). Carbon Dioxide Separation Technology: R\&D Needs For the Chemical and Petrochemical Industries, Chemical Industries Vision 2020 Technology Partnership, November 2007

Robeson, L.M. (2008). The upper bound revisited. J. Membrane Sci., vol. 320, pp. 390-400

Sanaeepur, H.; Ebadi, A.; Moghadassi, A. \& Kargari, A. (2011a). Preparation and characterization of Acrylonitrile-Butadiene-Styrene/Poly (vinyl acetate) membrane for $\mathrm{CO}_{2}$ removal, Sep. and Purif. Technol., Vol. 80, pp. 499-508

Sanaeepur, H.; Ebadi, A.; Moghadassi, A.; Kargari, A.; Moradi, S. \& Ghanbari, D. (2011b). A novel acrylonitrile-butadiene-styrene/poly (ethylene glycol) membrane: preparation, characterization and gas permeation study, Polym. Adv. Technol., DOI: 10.1002/ pat.2031

Song C.S., et al., (Eds.) (2002). $\mathrm{CO}_{2}$ Conversion and Utilization. American Chemical Society, Washington, DC, ACS Symposium Series, vol. 809, pp. 420-427

Song, C. (2006). Global challenges and strategies for control, conversion and utilization of $\mathrm{CO}_{2}$ for sustainable development involving energy, catalysis, adsorption and chemical processing. Catal. Today, Vol.115, pp: 2-32

Song, C.S.; Pan W. (2004). Tri-reforming of methane: a novel concept for catalytic production of industrially useful synthesis gas with desired $\mathrm{H}_{2} / \mathrm{CO}$ ratios, Catal. Today, 98 (4) 463-484

Stangeland A. (2007). A model for the $\mathrm{CO}_{2}$ capture potential, International Journal of greenhouse gas control, 1,418-429 
Stewart C. \& Hessami M. (2005). A study of methods of carbon dioxide capture and sequestration-the Sustainability of a photosynthetic bioreactor approach, Energy Conversion and Management, 46: 403-420

Stolaroff J K, Lowry G V, Keith D W, (2005). Using CaO- and MgO-rich industrial waste streams for carbon sequestration. Energy Conversion and Management, 46: 687-699

Takht Ravanchi, M. \& Kargari, A. (2009). New Advances in Membrane Technology, In: Advanced Technologies, K. Jayanthakumaran, (Ed.), pp. 369-394, InTech, ISBN 978953-307-009-4

Takht Ravanchi, M.; Kaghazchi, T. \& Kargari, A. (2008a). Separation of a Propylene-Propane Mixture by a Facilitated Transport Membrane, The $5^{\text {th }}$ International Chemical Engineering Congress (IChEC 2008), Jan, 2008, Kish Island, Iran

Takht Ravanchi, M.; Kaghazchi, T. \& Kargari, A. (2008b). Immobilized Liquid Membrane for Propylene-Propane Separation, Proceeding of World Academy of Science, Engineering and Technology, pp. 696-698, ISSN 1307-6884, Paris, July 2008, France

Takht Ravanchi, M.; Kaghazchi, T. \& Kargari, A. (2008c). A new approach in separation of olefin-paraffin gas mixtures by a membrane system, Amirkabir J. Sci. Res., Vol. 19, pp. $47-54$

Takht Ravanchi, M.; Kaghazchi, T. \& Kargari, A. (2008d). Application of facilitated transport membrane systems for the separation of hydrocarbon mixtures, $18^{\text {th }}$ International Congress of Chemical and Process Engineering, Praha, August 2008, Czech Republic

Takht Ravanchi, M.; Kaghazchi, T. \& Kargari, A. (2009a). Application of Membrane Separation Processes in Petrochemical Industry: A Review, Desalination, Vol. 235, pp. 199-244

Takht Ravanchi, M.; Kaghazchi, T. \& Kargari, A. (2009b). Separation of Propylene-Propane Mixture Using Immobilized Liquid Membrane via Facilitated Transport Mechanism, Sep. Sci. Technol., Vol. 44, pp. 1198-1217

Takht Ravanchi, M.; Kaghazchi, T. \& Kargari, A. (2010a) Facilitated Transport Separation of Propylene-Propane: Experimental and Modeling Study, J. Chem. Eng. Proc: Process Intensification., Vol.49, pp.235-244

Takht Ravanchi, M.; Kaghazchi, T. \& Kargari, A. (2010b) Selective Transport of propylene by silver ion complex through an immobilized liquid membrane, Iranian J. Chem. Eng., Vol. 7, No. 1, pp.28-41

Takht Ravanchi, M.; Kaghazchi, T. \& Kargari, A. (2010c) Supported Liquid Membrane Separation of Propylene-Propane Mixtures Using a Metal Ion Carrier, Desalination, Vol. 250, pp. 130-135

Takht Ravanchi, M.; Kaghazchi, T.; Kargari, A. \& Soleimani, M. (2009c). A novel separation process for olefin gas purification, J. Taiwan. Inst. Chem. Eng., Vol. 40, pp. 511-517

Torp, T. \& Gale, J. (2002). Demonstrating storage of $\mathrm{CO}_{2}$ in geological reservoirs: the Sleipner and Sacs projects, $6^{\text {th }}$ International Conference on Greenhouse Gas Control Technologies (GHGT-6), Kyoto, Japan, Oct.2002, Elsevier Science Ltd, Oxford, UK

UNFCCC, The Kyoto Protocol to the UN Framework Convention on Climate Change (UNFCCC-1992): http://unfccc.int/resource/docs/convkp/kpeng.pdf

WRI, (2008). CCS Guidelines: Guidelines for Carbon Dioxide Capture, Transport, and Storage. Washington, DC: WRI. Published by World Resources Institute 
Xu X, Song C S, Andresen J M, Miller B G, Scaroni A W, (2002). Novel polyethyleneiminemodified mesoporous molecular sieve of MCM-41 type as adsorbent for $\mathrm{CO}_{2}$ capture. Energy and Fuels, 16: 1463-1469

Xu X, Song C, Miller B G, Scaroni A W, (2005). Adsorption separation of carbon dioxide from flue gas of natural gas-fired boiler by a novel nanoporous "molecular basket" adsorbent. Fuel Processing Technology, 86(14-15); 1457-1472

Yamasaki A., (2003). An overview of $\mathrm{CO}_{2}$ mitigation options for global warming Emphasizing $\mathrm{CO}_{2}$ sequestration options. J. Chem. Eng. Japan, 36(4): 361-375

Yeh J T, Resnik K P, Rygle K, Pennline H W, (2005). Semi-batch absorption and regeneration studies for $\mathrm{CO}_{2}$ capture by aqueous ammonia. Fuel Processing Technology, 86(14- 15): 1533-1546 


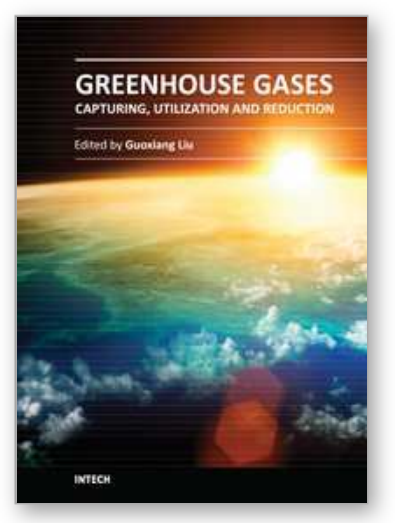

\author{
Greenhouse Gases - Capturing, Utilization and Reduction \\ Edited by Dr Guoxiang Liu
}

ISBN 978-953-51-0192-5

Hard cover, 338 pages

Publisher InTech

Published online 09, March, 2012

Published in print edition March, 2012

Understanding greenhouse gas capture, utilization, reduction, and storage is essential for solving issues such as global warming and climate change that result from greenhouse gas. Taking advantage of the authors' experience in greenhouse gases, this book discusses an overview of recently developed techniques, methods, and strategies: - Novel techniques and methods on greenhouse gas capture by physical adsorption and separation, chemical structural reconstruction, and biological utilization. - Systemic discussions on greenhouse gas reduction by policy conduction, mitigation strategies, and alternative energy sources. - A comprehensive review of geological storage monitoring technologies.

\title{
How to reference
}

In order to correctly reference this scholarly work, feel free to copy and paste the following:

Ali Kargari and Maryam Takht Ravanchi (2012). Carbon Dioxide: Capturing and Utilization, Greenhouse Gases - Capturing, Utilization and Reduction, Dr Guoxiang Liu (Ed.), ISBN: 978-953-51-0192-5, InTech, Available from: http://www.intechopen.com/books/greenhouse-gases-capturing-utilization-and-reduction/carbon-dioxidecapturing-and-utilization

\section{INTECH}

open science | open minds

\section{InTech Europe}

University Campus STeP Ri

Slavka Krautzeka 83/A

51000 Rijeka, Croatia

Phone: +385 (51) 770447

Fax: +385 (51) 686166

www.intechopen.com

\section{InTech China}

Unit 405, Office Block, Hotel Equatorial Shanghai

No.65, Yan An Road (West), Shanghai, 200040, China

中国上海市延安西路65号上海国际贵都大饭店办公楼405单元

Phone: +86-21-62489820

Fax: +86-21-62489821 
(C) 2012 The Author(s). Licensee IntechOpen. This is an open access article distributed under the terms of the Creative Commons Attribution 3.0 License, which permits unrestricted use, distribution, and reproduction in any medium, provided the original work is properly cited. 